DEUİFD XLVII/ 2018, ss. 101-138.

\title{
MU'TEZİLE KELÂMINDA BİR HAK EDİŞ OLARAK İVAZIN İLAHÎ VE İNSANÎ YÖNÜ
}

Hüseyin MARAZ*

ÖZ

Elem, insanoğlunun idrak ettiği ve şahit olduğu bir duygudur. Öyle ki insan dünyada, sebepleri farklı birçok acı ve felakete tanık olmaktadır. İlahi kaynaklı hastalık, sakatlık, musibetlerin yanı sıra hemcinsinin etkin olduğu zulüm ve haksızlıklara da maruz kalmaktadır. Kuşkusuz bütün bunların adli ilahî gereği bir karşıllğı olmalıdır. Elemleri iyi yapan bu bedel, Mu’tezile teolojisinde ivaz olarak ifade edilmektedir. Kulun Allah üzerinde veya kulun kul üzerinde bir hakk1 olarak ivaz, Mu'tezilî düşüncede Allah'a tazmini vacip olan bir fiildir. Zulüm ve elemin bedelinin ödenmesi ve yapılan kötülüğün kimsenin yanına kar kalmaması, kötülüğün ontolojik, bireysel ve sosyolojik varlığına dair makul bir izahtır.

Anahtar Kelimeler: Mu’tezile, Adalet, Zulüm, Elem, İvaz.

\section{THE DIVINE AND HUMAN ASPECTS OF 'TVAD AS A DESERVE IN MU'TAZILITE THEOLOGY}

\begin{abstract}
Pain is an emotion that mankind perceives and witnesses. To such an extent that mankind in this world is exposed to grief and calamities which stem from various reasons. Through divinely sourced illnesses, disabilities, and tribulations, man is ontologically exposed to pain. From another perspective, man is obliged to live through the injustice and oppression that his fellow humans participate in. Due to divine justice there must be a compensation for all this. This concept which provides a justification for pain is called ivaz in Mu'tazilite thought. Ivaz is defined as the right of a servant towards Allah or towards other servants of Allah. In Mu'tazilite thought, compensation for pain is condered an obligation on Allah. The recompensation of injustice and pain,
\end{abstract}

* Dr. Öğr. Üyesi. Bilecik Şeyh Edebâli Üniversitesi İslami İlimler Fakültesi Kelam Anabilim Dalı. huseyin.maraz@bilecik.edu.tr. ORCID ID orcid.org/0000-00019751-7396

Makalenin Hakemlere Gönderiliş Tarihi : 19/02/2018

Makalenin Hakemlerden Geliș Tarihi : 24/04/2018 
and the manifestation of justice is a logical explanation for the ontological, individual, and sociological existence of evil.

Key words: Mu’tazila, Justice, Injustice, Pain, Ivad/Compensation.

\section{Giriş}

Yaşamın bir parçası olan elemlerin varlığını inkâr eden yoktur. Çünkü elemin varlığına en açık bilgi idraktir. Hatta bir şey idrak alanına dâhil olduğunda artı bir delil aramaya da ihtiyaç yoktur. ${ }^{1}$ Zira insanoğlu farklı şekillerde ve şartlarda birçok acı, üzüntü ve 1stıraba tanık olmaktadır. Doğal afetler, hastalık ve sakatlıklar ve bunlara bağlı oluşan maddî ve manevî kayıplar vs. insanın kaçınamayacağ1 tabî̀ acılardır. ${ }^{2}$ Bunun yanında özellikle yüzyılımızda insan kaynaklı sayısız felaketlerin neden olduğu acılar da yașanmaktadır. Maalesef insanlar, dünyanın değişik yerlerinde hiç olmadığı kadar zulüm ve haksızlığa maruz kalmaktadır. Bireysel ve toplumsal çıkarlar uğruna kan ve gözyaşı içerisinde dayanılmaz acı ve felaketleri yaşamaya zorlanmaktadır. Öyle ki Allah, doğrudan sebep olduğu acıların bedelini ödemeyi üstlenmiştir. İnsanın hemcinsine karşı işlemiş olduğu zulüm ve haksızlıkların bedelini ödetmeyi de aynı şekilde kendi üzerine almıştır. ${ }^{3}$ Şüphe yok ki insanların ahlakî ve hukukî olarak birbirlerine terettüp eden haklarını en objektif şekilde değerlendirecek olan Allah'tır. Biz de makalemizde meselenin daha çok insana dönük yönünü ilahî boyutunu da dikkate alarak ele alacağız. Mu’tezile kelâmında insanın işlemiş olduğu zulüm ve hak ihlallerine terettüb eden bedelin mahiyetini ve keyfiyetini tasvîri bir yöntem ve ilave açıklamalarla irdeleyeceğiz.

\section{1. İvazın Lügat ve Istılâhî Anlamı}

“Avz” kökünden türeyen ivaz, 'bedel' ve 'karşılık' anlamına gelen bir kelimedir. Sözlükte "bir iş veya nesneye karşılık gelen bedeli ödemek"

\footnotetext{
1 Kâdî Abdulcebbar Ahmed el-Hamedânî el-Esedabâdî, el-Muğnî fî-ebvâbi't-tevbid ve'ladl, thk. Muhammed Khodor Nabha (Beyrut: Dâru'l-Kutubi'l-İlmiyye, 2012), 13: 216, 225.

2 Kâdî Abdulcebbar, el-Muğnî, 13: 377-378.

3 Kâdî Abdulcebbar, Şerhu'l-usûli'l-hamse, thk. Abdulkerim Osman (Kahire: Mektebetü-Vehbe, 1996), 504.
} 
anlamında yer almıştır. ${ }^{4}$ Kâdî Abdulcebbar (ö. 415/1025) ivazı, zarar karşılığında övgü ve yüceltmenin (tâzৃim) bitişmediği hak edilmiş fayda olarak tanımlamaktadır. ${ }^{5}$ Mu'tezilî terminolojide ivazın özelliği, hak edilmesine rağmen yüceltme (tâzim) ve onure etmenin (tebcil) kendisine bitişmemesidir. ${ }^{6} \mathrm{Bu}$ anlamı açısından ivaz, amaç ve niteliğiyle kendisini diğer fayda ve zarar nitelikli değerlerden ayıran özelliklere sahiptir. Öncelikle ivazın fayda olması, kendisini zarar olan cezadan nitelik olarak ayırmaktadır. Çünkü ivaz, acının bedeli iken; ceza günah ve kötülüğün ahlakî sonucudur. Buna göre hak edilen eleme hakaret (ihanet) ve aşağılamanın (istihfaf) bitişmesi ceza (ikab) olmaktadır. Hak edilmeyen eleme hak edilen faydanın bitişmesi ise ivazdır. Diğer bir ayrım ise ivazın hak edilme şartı, hak edilmeden elde edilen lütuf/tefaddulden farklı olmasıdır. ' Tefaddul, bağımsız ve koşulsuz faydalandırma iken; ivaz, bağımlı ve koşullu faydadır. Allah'ın faydalandırmak için yaratması insan için tefaddul olurken; yaratılışa ve teklif filine elemi bitiştirmesi ivazın nedeni olmaktadır. Fakat Allah, yaratılışın başlangıcında mükâfat veya cezaya yer vermemektedir. Ancak yaratılışla birlikte ivazın hak edilmesi mümkündür. Mükâfat ve cezada ise böyle bir anlam söz konusu değildir. Çünkü her iki değer, insanın sorumluluk alanı ile ilgili olduğundan ilim ve amelin varlı̆̆1 ile doğrudan ilintilidir. Bu bağlamda tâzim ve tebcilin ivazda yer almamas1, ivazın mükâfattan (sevab) farklı olduğunu göstermektedir. ${ }^{8}$ Öyle ki tâzim ve tebcîl, teklife bağlı olarak yalnızca mükellef varlıkların hak edebileceği değerlerdir.

$4 \quad$ Halil b. Ahmed el-Ferâhidî, "Avz”, Kitâbu'l-ayn, thk. Abdülhamid Hendâvî (Beyrut: Dâru'l-Kutubi'l-İlmiyye, 2003), 3: 255; Muhammed Murtazâ ez-Zebîdî, "Avz”, Tâcu'l-arûs, thk. Abdulkerim el-İzbâvî (Kuveyt: 1979), 18: 449; İlyas Çelebi, "İvaz”, Türkiye Diyanet Vakfi İlâm Ansiklopedisi, c. 23 (İstanbul: TDV Yay., 2001), 488-499.

5 Kâdî Abdulcabbar, Şerbu'l-usûli'l-hamse, 494; Tanımlar için ayrıca bk. Şerif elMurtazâ Ali b. Huseyn el-Musevî el-Bağdâdî, el-Hudûd ve'l-hakâik (Resâilu'ş-Şerif Murtazâ içerisinde), thk. Seyyid Ahmed el-Huseynî (Kum: 1405/1984), 2: 278.

$6 \quad$ Kâdî Abdulcebbar, el-Muğnî, 13: 342.

7 Kâdî Abdulcebbar, el-Muğnî, 13: 343.

8 Kâdî Abdulcabbar, Şerbu'l-usûli'l-Hamse, 488-499; Şerif el-Murtazâ Ali b. Huseyn elMusevî el-Bağdâdî, ez-Zehîra fî-ilmi'l-kelam, thk. es-Seyyid Ahmed el-Huseynî (Kum: Müessesetü'n-Neşri'l-İslâmî, 1411/1990), 239. 
Şu halde sevab, teklîfe bağlı olarak oluşan meşakkatin hak edilmiş karşılığıdır. İbn Metteveyh'e göre tek bir şeyin, iki farklı değerin hak edilmesini sağlaması mümkün değildir. Dolayısıyla meşakkat, sevabın yanında ayrıca ivazı hak etmenin gerekçesi değildir.' Buna göre sevab, bireyin özgür filli ile hak ettiği bedeldir. Bu bakımdan sadece itaat ve iyiliğiyle hak eden biri övülebilir aksi durumda ise yerilebilir. İvaz, bireyin kendi filine bağlı olarak hak edilmediğinden övgü ve yüceltme içermez. $\mathrm{Bu}$ durumda hak edilmeyen eleme herhangi bir bedelin hak ediş olarak eklenmesi zorunlu olmaktadır. Şu halde ivaz, ivazı verecek olanın doğrudan fiili olabilir. Fakat sevab, mükâfata ulaştıracak olanın başlangıçtaki fiili değildir. Sevap, bilgi sahibi mükellefin bilinçli olarak yaptığ1 eylemlerin bir sonucu olarak (bilgi ve amel) hak ettiği faydadır. İvaz ise bilgi ve kasıt olmasa dahi eleme karşılık gelen faydadır. ${ }^{10}$ Örneğin hastalık, Allah'ın bir fiilidir. Hastalığın bedelini verecek olan da O'dur. Mükellefin hak ettiği mükâfat ise Allah'ın insan iradesinden bağımsız olmayan koşullu bir fiilidir. Çünkü kişi bu tür bir eylemi kendi özgür iradesi ile ahlakî ve hukukî olarak istihkak edebilmektedir. Bu yönüyle ivaz, alış-verişteki bedele benzer iken; mükâfat ve ceza, iyi veya kötü tercihin ahlakî sonucudur. ${ }^{11}$

Kur'an'da geçmeyen ivaz kelimesi, hadislerde “malın karşılığında ödenen bedel”, "dünyada yaşanan hastalık ve felaketlerin karşılığ1 olarak ahirette verilecek mükâfat" anlamında kullanılmıştır. ${ }^{12}$ Kur'an'da ise daha çok hakların adil bir şekilde hükme bağlanacağını bildiren ifadelere yer verilmektedir. Örneğin, "süphe yok ki Allah, ibtilaf ettikleri bütün konularda

\footnotetext{
Ebu Muhammed İbn Metteveyh Hasan b. Ahmed, Kitabu'l-mecmû-fi'l-mubit-bi't-teklif, thk. Jan Peters (Kahire: 1986), 3: 91.

10 Kâdî Abdulcebbar, el-Muğnî, 13: 342.

11 Ebu Hilâl el-Hasen b. Abdillah b. Sehl el-Askerî, “Avz”, el-Furuku'l-luğaviyye, thk. Muhammed İbrahim Selim (Kahire: Dâru'l-İlm ve's-Sekafe, 1997), 237.

12 Çelebi, "İvaz" 23: 488-499; Örnek olarak: "Yorgunluk, sürekli hastalı, tasa, keder, sıkıntı ve gamdan, ayağına batan dikene varncaya kadar müslümanın başına gelen her şeyi Allah, onun hatalarm bağıs̆lamaya vesîle kılar." Bk. Buhârî, "Merdâ", 1, 3; Müslim, "Birr", 49; "Allah Teâlâ buyuruyor ki: "Kulumu, iki gözünü kör etmekle imtihan ettiğim zaman sabrederse, gö̋lerine karşıllk olarak cenneti veririm." Bk. Buhârî, "Merdâ", 7; Tirmizî, “Zühd”, 58.
} 
kiyamet günü insanlar arasinda bir büküm verecektir." ${ }^{\text {"13 }}$ Ayette bir hüküm ve ayrım/fasl gününden bahsedilmektedir. Benzer şekilde Hz. Peygamber'in (s.a.v.) "kizyamet günü boynuұsuz koyun boynuұlu koyundan bakekm alacaktı" "14 ifadesi de hakların eksiksiz bir şekilde sahiplerine teslim edileceğini bildirmektedir. ${ }^{15}$

Kâdî Abdulcebbar, genel anlamda elem-bedel arasındaki hukukî ilişkiyi 'intisâf' kavramıyla açıklamaktadır. İntisâf, bir şeyin karşılı̆̆ının tam olarak alınmasıdır. Hak ve adaletin temini noktasında her iki tarafa eșit muamele edilmesidir. ${ }^{16}$ Diğer bir deyişle hak sahipleri arasında hiçbir ayrım yapmaksızın onları adalet zemininde eşitlemektir. Bu anlamıyla intisâf, Allah'ın, insanlar arası ahlakî ve hukukî ilişkileri adalet ekseninde düzenlemesidir. Nitekim şahid âlemde de hakların hakkın taraflarına eksiksiz bir şekilde dağıtımı hukuken zorunludur. Mu'tezile kelâmında böyle bir zorunluluk, gaib âlemde de Allah'ın hakk1 ve adaleti gözetmesi anlamına gelmektedir. ${ }^{17}$ Kâdî Abdulcebbar, ivazın mahiyeti gereği intisâfı, ac1 verenden bir bedelin alınarak ac1 verilene aktarılması olarak tarif etmektedir. ${ }^{18}$ Buna göre mükellef veya gayri mükellefe verilen elemin bir bedeli vardir. Elem, Allah tarafindan verildi ise ivazı verecek olan O'dur. Allah'ın dışında bir başkası eleme neden olduysa ivaz söz konusu kişiden alınarak hak sahibine aktarılır. ${ }^{19}$

Kâdî Abdulcebbar'a göre Allah, bireyin fayda ve zararına olan hususlarda tedbîr üzere hareket etmektedir. Tedbîr, Mu’tezile'de özel bir fiildir ve mutlak bilginin varlığı ile doğrudan ilişkilidir. Bilginin fiil ile ilintisi ise mükellef adına sürekli iyi ve faydanın öncelenmesidir. ${ }^{20} \mathrm{Bu}$ yönüyle tedbîr, zarar olan eylemin taşıdığ1 fayda değerine işaret

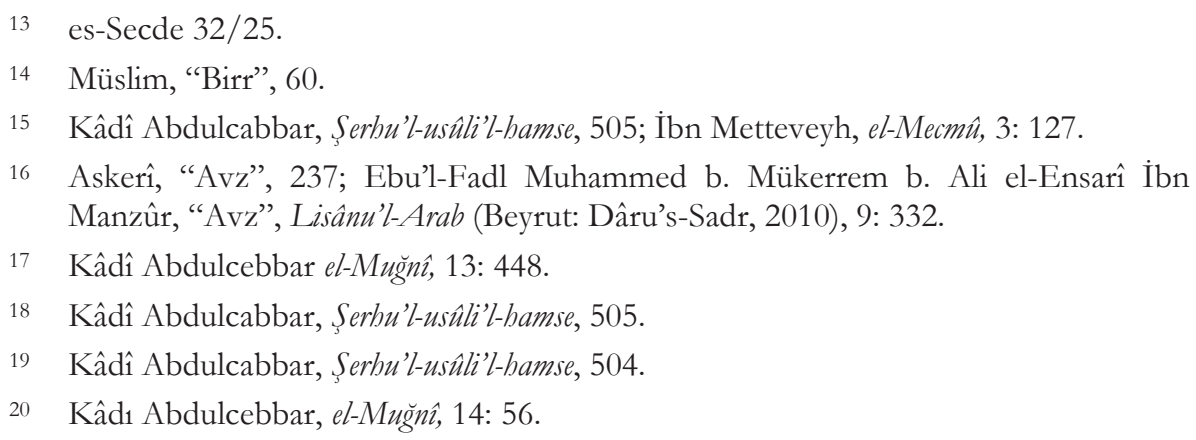


etmektedir. Kâdî Abdulcebbar da Allah'ın insanı ilgilendiren işleri idare etmedeki tasarrufunu, babanın evladı veya velinin velayeti altında olan kimsenin işlerini yürütmesine benzetmektedir. ${ }^{21}$ Örneğin bir velinin velayetinde olan yetim, bir başkasına zarar verse verilen bu zarar tazmini gerektiriyorsa veli zararı telafi etmek için yetimin malı üzerinde tasarrufta bulunur. Bu zararı tazmin etmek için yetimin malından tazmin miktarı kadar alır ve söz konusu zararın bedelini öder. Allah da insana verilen zararı tazmin etmek için zarar verenden bir ivaz alır. Alınan ivaz, zarara uğrayana verilerek mağdurun hakkı ödenmiş olur. ${ }^{22}$ Kâdî Abdulcebbar’a göre bu tarz hukukî işlem, adaleti sağlayan makul bir tasarruftur. Çünkü akıllı olan her varlık, hakkının zâyi olmamasını ve diğerinden hakkını eksiksiz olarak almayı ister. Onun düşüncesinde bilgi sahibi ve temkîn gücüne sahip her insanın başkasında olan hakkını alması; kendi üzerinde bulunan bir başkasının hakkını da ona ödemesi ahlakî ve hukukî açıdan yasal bir zorunluluktur. ${ }^{23} \mathrm{Bu}$ zorunluluğu adaletin merkezine çeken faktör ise yaşanılan ve yaşatılan acılara karşılık bir bedelin olduğu düşüncesidir.

\section{2. İvazı Zorunlu Kılan İlahî ve İnsanî Kaynaklı Elemler}

Câhız (ö.255/869), dünyanın başlangıcından sonuna kadar zıtlıkların bir arada olacağını söyler. Dünya hayatı ona göre iyi-kötü, hayır-şer, zararl1-faydalı, çirkin-güzel vb. zıtlardan oluşan bir karışım alanıdır. Fakat bütün bunların varlığında fayda ve maslahat söz konusudur. Ona göre dünyada sadece şer olsaydı varlık adına bir şey kalmaz, her şey yok olurdu. Yine dünya sadece hayır ve iyi şeylerden müteşekkil olsaydı imtihan sona erer; dolayısıyla varoluş anlamını yitirirdi. Her şeyin tekdüze olduğu bir alanda düşünme ve akletmenin sebep ve hikmeti de yok olurdu. Akletme imkânı olmayan bir alanda ise değerlerin varlık bulması söz konusu olmazd1. ${ }^{24}$

21 Kâdî Abdulcebbar, el-Muğnî, 13: 448, 450; Şerhu'l-usûli'l-hamse, 505

22 Kâdî Abdulcebbar, el-Muğnî, 13: 448; Şerhu'l-usûli'l-hamse, 505; İbn Metteveyh, elMecmû, 3: 127.

23 Kâdî Abdulcebbar, el-Muğnî, 13: 448.

24 Ebû Osman Amr b. Bahr b. Mahbûb el-Câhız el-Kınânî, Kitabu'l-hayevân, thk. Abdusselam Muhamed Harun (Kahire: 1965), 1: 204. 
Bununla beraber hayırlı olanı ve iyiyi tercih ve ayırt etme melekesi kaybolur; âlim için tespit, tavakkuf ve öğrenme yolu kapanırdı. İlim olmayınca anlama ve izah etmeden söz edilemezdi. Böylece zararı def etme, faydayı talep etme yöntemi bilinemezdi. Kötü şeylere sabır; sevilen ve arzulanan şeylere şükür gerçekleşmezdi. Değerler arasında kategorik olarak bir sınıflama imkânı kalmaz, üstünlük ve derece ayrımı yapılamazd. Zaferin ve izzetin sevinci ve onuru tadılamaz; korkular, ümitler, arzular, güven, acılar, lezzetler, hüzünler ve hazlar vs. bilinemezdi. Böylece de insanların meleklerden bir farkı kalmazd ${ }^{25}$ Her şeyin eşitlendiği bir dünyada ayırt etme yeteneği kalmaz; buna bağlı olarak külfet, bedel ve mükâfat gibi değerlerden bahsedilemez sonuçta da varoluş anlamını yitirirdi. ${ }^{26}$

Câhız’a göre insanı olgunlaştıran ve ehlileştiren bu zıtlıklardır. Bunların sayesinde insan, değersel bir gelişim (1slâh) sağlar ve neticede şer hayra, nefret sevgiye dönüşür. ${ }^{27}$ Âlemi zıtlıkların bir karışım alanı olarak yaratan Allah'ın insan için en iyi ve yararlıyı tercih ettiğinde ise şüphe yoktur. Buna göre dünya, lezzet ve nefretin idrak edildiği bir alan olarak herkese hitap eden ortak değerleri barındırmaktadır. Dolayısıyla insanın çektiği acılara karşılık olarak daha üst faydayı elde edeceği bilgisi elemlere karşı olumlu bir bakış açısı kazandırır. Bu sayede insanlar acılara sabredebilir ve güç yetirebilir. Daha büyük bir faydanın hak edileceği umuduyla elemleri sabırla olağan karşılar. Başına gelen acı ve felaketlere tahammül gösterebilir. ${ }^{28}$ Böylece elemler, insanın içsel rıza ve onayı ile makulleşir; daha büyük bir hayrı ve faydayı elde etmek için bedihî/apaçı bir tecrübeye dönüşür. ${ }^{29}$ Insan, bütün bunlarda bir hikmet ve gayenin olduğu bilgisiyle olgu ve olaylara kötümser bir bakış açısıyla yaklaşmaz. Çünkü her bir birey, imtihan alanı olan yeryüzünde değişik ve farklı etkilerde birçok acı ve istırapla karşı karşıya kalmaktadır. Bu bağlamda Mu'tezile, genel olarak insanın dünya ve ahiret ölçeğinde başına gelebilecek elemleri üç kategoride değerlendirmektedir.

\footnotetext{
Câhız, Kitabu'l-hayevân, 1: 204.

Câhı, Kitabu'l-hayevân, 1: 205.

Câhız, Kitabu'l-hayevân, (1965), 2: 88.

Hasan Hanefî, Mine'l-akîde ila's-sevra (Beyrut: 1988), 3: 515.

29 Hanefî, Mine'l-akî̀de ila's-sevra, 3: 518.
} 
1. Mükellefin özgür seçimi ve iradesiyle yaptığ1 kötülük ve işlediği günahların sonucunda hak ettiği cezanın verdiği elem. Mükellefin bu elem türünde bir ivaz elde etmesi mümkün değildir.

2. Tabiî felaketler, acılar, hastalık ve sakatlıklar, hayvanların boğazlanması ve insana musahhar kilınması sonucu meydana gelen elemler. Yaşanılan bu elemlerin bir bedeli vardır. Çünkü bu elemler, insan kaynaklı değildir. Hak sahibinin çektiği acılara karşılık gelen bedelin ödenmesi, Allah için bir ahlakî ve hukukî gereklilik (vâcib) doğurur.

3. Allah'ın iradesi dışında gerçekleşen insan kaynaklı elemler. Bu elem türü, yatay zeminde yani insanlar arası ilişkilerde açığa çıkmaktadır ve öncesinde herhangi bir ilahî müdahale ve belirleme söz konusu değildir. İlahî adaletin gereği olarak bu elemlere sebep olanlara bedeli mutlaka ödetilir. Ödetme yolu ise iki şekildedir. Zalimin var olan iyilikleri mazluma aktarılır. Zalimin iyilikleri yoksa Allah, mükellefin elemlerini alır ve ona bedelini tazmin eder. ${ }^{30}$ Ancak bu elemler vasitalı olduğundan Allah'ın fili konumunda kabul edilir ve işlev ve sonuçları bakımından iyi (hasen) bir niteliğe sahiptir. Bu temelde denilebilir ki dünyada insanların maruz kaldığı elemlerin iyi kategorisine girebilmesi, iki koşulu sağlamasına bağlıdır.

1. Acılar, bir hak ediş olarak karşılluğ (ivaz) olan bir tecrübedir.

2. Bu tür durumlar, fonksiyonel açıdan değer yüklü (maslahat) bir kazanıma aracılık ederler. Bu ise acıya maruz kalan veya bir başkası için lütfun varlığ1 anlamına gelmektedir. Çünkü bir kimseyi ivaz takdir etmeksizin acılara maruz birakmak zulümdür. Katlanılan acıların daha büyük faydalara ulaştıracak olması ise lütuftur. Elemin bir başkası için

30 Muhammed Salih Muhammed es-Seyyid, el-Hayr ve'ş-şer inde'l-Kâdî Abdilcebbar, (Kahire: 1998), 145; Tûsi (ö. 672/1274) ilahi kaynaklı elemleri biraz farklılıklarla şöyle taksim eder. Hastalık gibi mükellefin başına gelen varoluşsal elemler. Mükellefin malının helak olması veya evladının ölümü gibi menfaatin engellenmesiyle meydana gelen elemler. Bu tür elemler zarar verme konumundadır. Musibetler gibi mükellefin üzüntü duyacağı sebepleri Allah'1n var etmesiyle yaşanan elemler. Bu da zarar verme konumundadır. Hayvan boğazlamak gibi Allah'ın emriyle gerçekleşen elemler. Hayvanların var olma mücadelesi sonucu oluşan elemler. Bk. Ebu Cafer Muhammed b. el-Hasen et-Tûsî,, Kesfu'l-Murâd fì-serbi'ltecrîdi'l-itikâd,. şrh. Allâme Hillî (Beyrut: Müessesetu'l-Âlemî, 1988), 311-312. 
lütuf olması aynı zamanda bir fayda ve iyiliğin hedeflenmesi ile (garaz) de açıklanabilir. İnsana hiçbir gaye ve amaç gütmeksizin ivaz karşılığında acılar yaşatmak ise anlam ve amaç dışı (abes) fiildir. Öyleyse acıların bir de maslahat boyutu olmalıdır. ${ }^{31} \mathrm{Bu}$ yüzden elemler, faydanın hak edilmesi ve dünyada yaşayanlara ibret olması için makulleşebilen olgulardır. Yani bedeli hak etmek, elemin sonucu iken; ögüt almak, sorumlu davranış ve acının fâili olmayı engellemek içindir. ${ }^{32}$ Kısacası insanlar, elemler neticesinde varllğa karşı duyarlllık kazanmakta merhamet ve acıma duygusu ile başkasına eziyet etmeme hassasiyetine sahip olabilmektedir. $\mathrm{Bu}$ açıdan yaklaşıldığında Allah'ın insanın menfaatine olan bir fiile yöneldiği de söylenebilir.

Nitekim Mu'tezile kelâmında genel kanaat, kulları için aslah olanı yaratmanın Allah'a vacip olduğudur. ${ }^{33}$ Ebu Haşim, aslah ile dünyada din konusunda mükellefin maslahat ve menfaatine olan şeyleri kastederken; Kâdî Abdulcebbar aslahı, dünyada mükellefiyet için en yararlı olan şeylerle sınırlandırmaktadır. ${ }^{34}$ Diğer yönden Kâdî, salahı, fayda olarak tanımlar ve bununla iyi-doğru, sevinç-lezzet veya her ikisine neden olan şeyleri anlar. Bu bakımdan o, sevinç ve lezzete sebep olan zararın da fayda olduğunu düşünür. ${ }^{35}$ Şu halde faydaya götüren elem, o an için zarar verse de özünde iyi bir değer de taşımaktadır. Kâdî Abdulcebbar, aslab’ (üst fayda) Allah'1n, sadece lezzet ve sevinç veren şeyleri yaratması olarak anlamaz ve acı da verse lezzete götüren şeyleri faydalandırmak için yaratılabileceğini belirtir. Aksi düşünüldügünnde dünyada yaşanılan acı ve zararı açıklayabilmek imkânsız hale gelmektedir. Dolayısıyla aslah, sonuç itibarıla en doğru ve yararlı olana neden olan fiildir. ${ }^{36}$ Tecrübî âlemde de hacamat yaptırmak veya hoş olmayan bir ilacı tedavi amacıyla içmek o

31 Meysem b. Ali b. Meysem el-Bahranî,, Kavâidu'l-merâm fî-ilmi'l-kelâm, thk. Seyyid Ahmed el-Huseynî (Tahran: 1905), 119.

32 Hanefî, Mine'l-akîde ila's-sevra, 3: 517-518.

33 Kâdî, aslahın yaratılış öncesinde Allah'a vacip olmadığını; yaratılışla beraber hikmet ve adalet üzere mükellefiyet ile ilgili konularda vacip olduğunu söyler. Bk. Kâdî Abdulcabbar, Muğnî, 13: 30.

34 Kâdî Abdulcabbar, Muğnî, 13: 43.

35 Kâdî Abdulcabbar, Muğnî, 13: 41.

36 Kâdî Abdulcebbar, el-Muğnî, 14: 55-56. 
anda elem verse de sonuç itibariyle sağlık ve iyileşme amacı içerdiğinden aslahtır. Yine insanların para kazanmak ve rahat yaşamak için yorucu ticarî yolculuklarda bulunmaları faydadır. ${ }^{37}$ Benzer şekilde Allah da birtakım faydaları, geçici zararlar karşılığında va'd edebilmektedir. Şu halde Mu'tezilî düşüncede bir şey fayda sağlıyor veya kendisinden daha büyük bir zararı ortadan kaldırıyorsa o anda acı da verse koşullu anlamda iyi ve faydadır. ${ }^{38}$

Diğer yönden Mu'tezile, sonucu fayda olan veya hak edilen zarar1, 'iyi zarar' terkibiyle ifade etmektedir. Ayrica onlar hayr1, fayda veren veya bu amac1 sağlayan her şey; şerri de özü itibariyle kötü zarar ve buna sebep olan her şey olarak anlamaktadır. Buna göre iyi zarar olarak ifade ettikleri ahirette ceza (ikab) verme, dünyada elemlere maruz birakma ve hadleri uygulama vs. Allah'ın kötü filili değildir. Onlara göre mükellefin maruz kaldığı her acı ve 1stırap, kötü zarar olarak anlaşılmamalıdır. ${ }^{39}$ Çünkü zarar, kötü (kabih), abes ve haksiz niteliklere sahip olursa herhangi bir fayda sağlamaz ve zulüm niteliği kazanır. Bunun yanında elemin verdiği zararı Allah'ın karşılayacak olması, bunların kötü olmadığını göstermektedir. Zira Allah'ın kasttlı ve bilinçli fiiline kötü bir niteliğin bitişmesi imkânsızdır. Bu sebeple Allah, hastalık ve 1stırapların karşllı̆̆nda daha üst menfaatleri ahirette insana bir hak olarak verecektir. Kâdî'ya göre böyle bir va'd olmaksızın Allah'ın insanlara elem vermesi iyi (basen) değildir. $\mathrm{O}$, bu durumu tecrübî âlemde bir işçi kiralayan, ona istenilen işi yaptırıp iyice yorduktan sonra ücretini ödemeyen kimseye benzetir. Böyle bir davranış beşeri düzlemde doğru ve iyi değildir. ${ }^{40}$

37 Kâdî Abdulcebbar, el-Muğnî, 14: 55-56; Şerbu'l-usûli'l-bamse, 484; Zühdî Cârullah, elMuteqile, (Beyrut: 1974), 104; Aslında insanoğlunun temel problemi merhameti yanlış anlamasıdır. İnsan acı veren birinin merhametsiz olduğunu düşünür. Allah'ın katlanmak zorunda oldukları acıları kullara yaşatması merhametsiz olduğunu göstermez. Çünkü acı ve 1stıraplar tedavi edici bir ilaç gibidir. Allah bu yöntem ile insanlar1 1slah etmektedir. Bk. Eric Lee Ormsby, Íslam Düşüncesinde İlabi Adalet Sorunu, trc. Metin Özdemir (Ankara: Kitabiyat Yayınlar1, 2001), 248.

38 Kâdî Abdulcebbar, Muğnî, 13: 266.

39 Kâdî Abdulcebbar, Faz̧lu'l-itizal ve tabakâtül-mu'tezile, thk. Fuad Seyyid (Kahire: Dâru'l-Kutubi'l-Misriyye, 1967), 179.

40 Kâdî Abdulcebbar, el-Muğnî, 14: 55-56; Faysal Bedir Avn, el-Usûlu'l-bamseti'l-mensûbîila'l-Kâdî-Abdilcabbar b. Abmed el-Esedî el-Ebâdî̀ (Kuveyt: 1998), 84. 
Çünkü zararın karşllı̆̆ı başka bir zarar değildir. Öyleyse Mu’tezilî düşüncede ivaz, verilen zararın karşıllı̆ında canlı varlığın hak ettiği bir değer olarak Allah'ın yerine getirmesi gerekli bir haktır.

Bunun aksine genel olarak Mücebbire ve Eş'arîler, Allah'ın ivaz olmaksızın elem vermesini iyi kabul etmekte ve Allah'ın fiiline sinır koyulamayacağını söylemektedir. Çünkü onlara göre insan için kötü olan bir fiil, Allah söz konusu olduğunda adl ve iyi (basen) değeri kazanmaktadır. Zira canlıları yaratan ve onların mâliki olarak her türlü tasarruf yetkisine sahip olan O'dur. İsterse ateşin içerisinde canlıları yaratarak ebediyen orada onlara azap edebilir. Bu şekilde acı vermesi, sırf onları yaratmış olmasından dolayı iyi nitelik bildirmektedir. ${ }^{41}$ Eş'ariler mülkiyet mantığı ile meseleye yaklaştıklarından ahlakî zeminden uzak bir yaklaşım içerisinde olmuşlardır. Çünkü onların düşüncesinde Allah'ın fillerinin sorgulanması aklen ve dinen muhaldir. Mu'tezile ise adl ilkesi gereği, Allah adına böyle bir fiilin kötü olduğunu öncelikle kabul eder. Onlara göre kudret ve mülkiyetin esas alınarak hikmet ve gayeden yoksun olan gerçekleşen bir fiil, kötülük yapan bir Allah tasavvurunun oluşması demektir. Mu’tezile kelâmında ise Allah, bütün kötülüklerden tenzih

41 Kâdî Abdulcebbar, Şerbu'l-usûli'l-hamse, 483-484; Rüknüddîn İbnü'l-Melâhimî elHavârizmî, Mahmud b. Muhammed, Kitabu'l-fâik fi-usûli'd-dîn, thk. Faysal Bedir Avn (Kahire: 2010), 324; Elemlerin iyi mi yoksa kötü mü olduğu hususunda farklı birçok görüş ortaya atılmıştır. Bunları maddeler halinde şu şekilde sınıflandırabiliriz:

1.Seneviyye'ye göre elemlerin tamamı kabih; bütün lezzetler hasendir.

2.Bir başka grup elemlerin sadece hak edildiği takdirde iyi olacağ1 görüşünü benimsemiştir. Fakat bu grup çocuk ve hayvanların elemlerine şahit olduktan sonra iki ayrı düşünceye sahip olmuştur.

a. Tenasuh ehline göre elem gören çocuklar başka bir bedende isyan ettikleri için şimdiki bedenlerinde acılara maruz kalmaktadırlar. Fakat onların bedenleri değil ruhları acı içerisindedir.

b. Bekriyye'ye göre bu çocuk ve hayvanlar acıları hissetmemektedirler.

c. Mücebbire elemlerin iyi veya kötü olarak taksimini fâil ile ilişkilendirmiştir. Elemlerin fâili Allah ise iyi; O'nun dışında bir başkası ise kötüdür.

d. Kadı Abdulcebbar'a göre elemlerin iyi veya kötü olması fiille ilişkilidir. Bir fiil bazen iyi olabilirken bazen de kötü olabilir. Bir fiil fayda sağllyor ve zararı engelliyorsa acı da verse iyidir. Ayrıntılı bilgi için bk. Kâdî Abdulcebbar, el-Muğnî, 13: 213, 216; Şerbu'l-usûli'l-hamse, 483; Abdurrahman Bedevî, Mezâhibu'l-islâmiyyîn, (Beyrut: Dâru'l-İlm, 1998), 469 
edildikten sonra filllerinin hikmet ve gayesi tartışılmıştır. Onlar, Eş'ariler'in Allah'ın hukukunu savunmaya ayırdığ1 tenzîhî dili, hayat ve varlık alanında insan hukukunu savunmaya ayırarak, Allah'ın kötünün fâili olamayacağı ilkesini ahlakî düzlemde ele almışlardır. İnsanların hak ve hukukuna en hassas şekilde riayet edecek olanın Allah olduğunu ahlakî bir ilke olarak benimsemișlerdir.

Diğer açıdan Mu'tezile, bedel taşımaksızın zarar ve acı vererek yaratma ve tasarrufta bulunmayı abes olmakla nitelemiştir. Çünkü onların düşüncesinde, sebepsiz yere bir varlığa eziyet etmek, ulûhiyet açısından sorunlu bir tutum olarak anlaşılmıştır. Bu minvalde İbn Melâhimî (ö.536/1141), lütuf, ibret, gaye ve garazdan yoksun bir eylemin hiçbir şekilde anlam ve tutarlılığının olmayacağını vurgulamaktadır. ${ }^{42} \mathrm{Bu}$ bakımdan elemleri kötü kılacak iki şeyin varlığına özellikle vurguda bulunmuşlardır. Elem ivazsız olursa zulüm; ibretten yoksun olursa abestir. ${ }^{43}$ Her iki durumun varlığ1 halinde ise elem kötü bir değer kazanmaktadır. Kötü kategorisi ile Allah arasında olumsal bir nispet ilişkisi kurmak ise Mu’tezilî düşüncede imkânsızlıkla nitelenmiştir.

\section{3. İvazın Allah'a Vâcip Olması}

Mu'tezile kelâmında Allah'a vacip olan ivaz, O’nun kullarına lütuf ve inayetinin en açık göstergesidir ve asla zulmetmeyeceğini güçlü bir şekilde ifade etmektedir. Öyle ki Allah, hastalıklar vererek, musibetlerle sinayarak, acı ve 1stıraplara maruz birakarak, hayvan boğazlamayı ibadet olarak emrederek esasında bir bedel ödemeyi üstlenmiştir. ${ }^{44} \mathrm{Bu}$ şekilde

42 İbn Melâhimî, Kitabu'l-fâik, fì-usûli'd-dîn, 324.

43 Kâdî Abdulcebbar, el-Muğnî, 13: 266; Serhu'l-usûli'l-hamse, 485; İbn Metteveyh, elMecmû, 3: 28, 42; Ebu Ali'ye göre sadece ivaz karş1lı̆̆ında elem vermek iyidir. Ebu Haşim'e göre mücerred ivaz yeterli değildir. Ayrıca elem, diğer insanlar için ibret olmalıdır. Kâdî Abdulcebbar da bu görüşü kabul eder. Allah, elem vermeden de ivaz verebilir. Öyleyse elem vermede amaç sadece ivaz değildir. Bu durum ücretle bir kimseyi kiralayıp ondan bir nehirden bir başka nehre su aktarmasını istemeye benzer. Böyle bir iş abes ve amaçsızdır. Bk. Kâdî Abdulcebbar, Şerbu'l-Usûli'lHamse, 493; İvaz olmaksızın elemin hasen olduğunu söyleyen Abbad b. Süleyman'dır. Ona göre elemde ibret alma şartı yeterlidir. Fakat Kâdî, gayri mükellef varlıkların elemden ibret alma imkânı olmadığından ivazın zorunlu olduğunu söylemektedir. Bk. Kâdî Abdulcebbar, Şerbu'l-usûli'l-bamse, 490.

44 Kâdî Abdulcebbar, Şerbu'l-usûli'l-hamse, 484; Seyyid, el-Hayr ve'ş-şer, 145. 
Kâdî Abdulcebbar, dünyadaki kötülük ve acıların teolojik gerekçesini bedel teorisi ile izah etmektedir. Bu aynı zamanda Allah'n fillerinin iyi yönler (vech) taşıdığı, kötü ve anlam ve amaç dış1 yönlerden uzak olduğu ve adaletin mutlak varlığ1 ve işlevselliği anlamina gelmektedir. ${ }^{45}$ Şu halde Allah'in elem vermesi ya faydalandırma ya da hak ediş üzerinden gerçekleşmektedir ki bunun teknik ifadesi, bedel (ivas) ve ceza (ikab)tır.

$\mathrm{Bu}$ nedenle Mu'tezile, zarara engel olmak için elem vermeyi iyi olarak ifade etmemiştir. Daha doğrusu onlara göre elemi iyi yapan salt zararın varlığı değildir. Elemin faydaya ulaştıracak olması, eleme iyi değer katmaktadır. Yani elem, zararı zarar ile def etmek değil; zarara karşılık olarak bir faydanın var edilmesidir. Bir bakıma sonraki fayda nedeniyle önceki zarar telâfi edilmektedir. Buna karşın Mu’tezile'den Ebu'l-Kasım el-Belhî (ö.319/931), Allah'ın zararı defetmek için elem verebileceğini ileri sürmüştür. $O$, daha çok muhatabın kendisi veya bir başkası için elemin pratik yararına vurguda bulunmak istemektedir. Örneğin günahların temizlenmesi için insana hastalık verilmesi ona göre menfaattir. Bu şekilde zararı uzaklaştırmak için eleme müracaat edilmiştir. Ebû Reşîd en-Nisâbûrî ise (ö.415/1024), Mu'tezile'nin önde gelen âlimleri tarafından bu görüşün revaç bulmadığını belirtir. Çünkü zarara engel olmak için bir kimseyi acılara maruz bırakmak fayda ise acı vermeden faydanın sağlanması yine mümkündür. Üstelik elem, zararı def etme yöntemi kabul edilir ise zararı uzaklaştırmanın başka yolu da kalmayabilir. Böyle bir durum, elem olmaksızın bir zararı yok etmenin iyi olmadığı anlamını da taşımaktadır. Buna göre Allah'ın zarar vermeksizin zarara engel olması mümkünse, zarara engel olmak için zarar vermesi kötü olmaktadır. ${ }^{46}$ Zira fayda taşımayan zarar da zulüm, kötü veya anlam ve amaç dışı bir davranıştır. Öyle ki Mu’tezile düşüncesinde elem, zararın ahlakî karşıllı̆ı olması yanında faydanın nedenidir. Ayrıca elemin fayda olması, ivazı içerisinde barındırdığı için yararlı (salab) olduğu anlamına da gelmektedir. Yani elem, sadece ivaz olduğu için bir zararın verilmesi değil; aynı zamanda fayda olduğu için ivazın zorunlu olması demektir. ${ }^{47}$

\footnotetext{
45 Seyyid, el-Hayr ve's-şser, 146.

46 Ebu Reşîd Said b. Muhammed b. Said en-Nisâburî, Mesâilu'l-bilâf-beyne'l-basriyyîn ve'lbağdadiyyîn, thk. Maan Ziyade-Rıdvan es-Seyyid (Beyrut: 1979), 169.

47 Nisâburî, Mesâilu'l-bilâf, 169-170.
} 
Öyleyse zararı yok etmek için zarar vermek muhaldir. Yine Allah'ın bir zarara engel olurken başka bir zararı tercih etmesi de imkânsızdır. ${ }^{48} \mathrm{Bu}$ iki koşul Allah için düşünülemediğinden sadece faydalandırmak için elemlerin yaratıldığı sonucu kaçınılmaz olmaktadır. Nitekim Allah, zararı def etmek için zarar vermediği gibi, üst bir zarara engel olmak için basit bir zarara da başvurmaz. Öyle ki Mu'tezile kelâmında zararın bedeli zararı ortadan kaldırmak değil sadece faydalandırmaktır. Çünkü bir zarara engel olunacak ise zarar, zarar verenin (Allah) fiili olmamalıdır. Yani Allah'in birine zarar vererek zarar1 uzaklaştırması imkânsızdır. Buna sebep Allah'ın def edemeyeceği bir zarar türünün olmamasıdır. ${ }^{49}$ İvaz ise zararın taşıdığ 1 fayda değeridir.

Daha doğrusu Mu’tezilî düşüncede insan, faydalandırılmak için yaratılmış ve faydayı hak etmesi için de teklîfi emre muhatap olmuştur. Bundan dolayı 'zarara engel olma amacı' yaratılışın gayesine ait bir değer değildir. Bununla birlikte Mu'tezile'nin ivaz anlayışında insan, zararı değil; faydayı hak etmektedir. İvazın bağlayıcılık doğuran yönü de acıların insanın hak edişi ile ilişkili olmamasıdır. İnsanın kendi irade ve tercihiyle hak etmediği ivaz, ancak bir başkasının eylemiyle hak edilmektedir. Allah'ın zalime zulüm filini işleme firsat ve imkânı vermesi, mazlumun ivaz hakkına sahip olduğu anlamina gelmektedir. Bu sebeple Kâdî Abdulcebbar, ivaz, "tefaddul konumunda olduğundan fasığa veya kâfire verilmeyebilir" düşüncesini doğru bulmaz. Ona göre tefaddul, Allah'ın yapıp yapmamakta serbest olduğu 'mahza iyilik' fiilidir ve bir zorunluluk taşımamaktadır. Allah'ın hastalık vermesi, musibetler ile sınaması ise ivazın kendi üzerine vâcip bir hak olması demektir. Çünkü elemin neticesinde oluşan zarar, Allah tarafindan meydana getirilmiştir. ${ }^{50}$ Allah'ın bütün fillleri hikmet ve iyi olduğuna göre de faydanın varlı̆̆ zorunlu olmaktadır. ${ }^{51}$ Bunun yanında Allah, iyi olan fiili sadece iyilikte bulunmak

48 Örneğin boğulan birini, elini kırmadan kurtarma imkânı varken elinin kırılarak kurtarılması, kabih olduğu gibi ayrıca ivaz hakkını doğurur. Bk. Tûsi, Tembîdu'l-usûl, 340.

49 Ebu Cafer Muhammed b. Hasen et-Tûsi,, Tembîdu'l-usûl (fì-İlmi'l-Kelâm), (Şerif Murtazâ’nın Cümelü’l-İlmi ve'l-Amel adlı eserinin ilk bölümüne yazılan şerh), thk. Merkezü’t-Tehassusi li-İlmi'l-Kelami'l-İslamî (Kum: 1396/1976), 340.

50 Kâdî Abdulcebbar, el-Muğnî, 13: 416.

51 Kâdî Abdulcebbar, el-Muğnî, 14: 50, 65. 
(ihsan) için yapmamaktadır. İyi fiili özü gereği iyi olduğu için yapmaktadır. ${ }^{52} \mathrm{Bu}$ açıdan düşünüldüğünde Allah'ın ivaz vermesi basit bir ihsan değildir. Vacip bir eylem olarak iyi ve doğru niteliğine sahip bir eylemdir.

Kâdî Abdulcebbar da bir fiilin iyi olmasını nefy; kötü olmasını ispat yöntemiyle izah etmektedir. Buna göre zarar, kötü yönlerden nefy edildiğinde iyi değeri kazanmaktadır. Burada zararın iyi olması kötü yönlerin yokluğu nedeniyledir. Ayrıca kötü bir yönün (vech) bitişmediği fiil, zulüm veya abes olmaktan da uzaktır. ${ }^{53}$ Elemler de zülüm ve abes olmadıklarından iyi niteliğe sahiptir. Bundan dolayı ivaz hakkı iman ve itaat ile ilintili bir hal değildir. Sadece yaratılmış olmak, ivaz hakkına sahip olmayı gerektirebilmektedir. Kâdî Abdulcebbar da ivazı hak eden varlığın, mükellef veya gayri mükellef olabileceğini söyleyerek bu olguya işaret etmektedir. Buna göre mükellef, cennet ehli gibi faydalanması iyi olan biri de olabilir; zarar verilmesi iyi olan cehennem ehli de olabilir. Mükellef olmayan varlıklar ise hak ettikleri oranda fayday1 hak etmektedir. ${ }^{54}$ Kısacası Kâdî Abdulcebbar, ivazın hak edilmesinde inanan veya inanmayan ayrımı yapmamaktadır. Onun düşüncesinde bütün canlılar, varlık alanında yer almakla ivazı hak edebilir. ${ }^{55}$

Kâdî Abdulcebbar, inanmayan birine ölmeden önce dünyada iken fayda sağlama veya ahirette cezasından hafifletme şeklinde ivaz sağlanabileceğini söyler. ${ }^{56} \mathrm{Bu}$ tür fayda, ona göre faydalandırma konumundadır. Bu nedenle Kâdî, 'ceza nedeniyle ivaz verilmesi imkânsız olan birinden ivazın düşmesi gerekir' düşüncesini doğru bulmaz. Çünkü cehennemi hak eden kimse de zulme uğramış biri olabilir. Böyle biri intisaf koşulu gereği hak ettiği ivaz ile faydalanmalıdır. Kâdî Abdulcebbar'a göre hak edilen ivazın vucûbiyetine engel olan bir durumun varlığı mümkün değildir. Öyle ki günahkâr biri, kesintili de olsa azaptan önce hak eden ivazdan istifade etmelidir. ${ }^{57}$ İbn Melâhimi,

\footnotetext{
52 Kâdî Abdulcebbar, el-Muğnî, 13:162.

53 Kâdî Abdulcebbar, el-Muğnî, 13: 283.

54 Kâdî Abdulcebbar, el-Muğnî, 13: 443.

55 Kâdî Abdulcebbar, Şerbu'l-usûli'l-hamse, 485.

56 Kâdî Abdulcebbar, Şerbu'l-usûli'l-hamse, 504.

57 Kâdî Abdulcebbar, el-Muğnî, 13: 416.
} 
Allah'ın irade ve eyleminin iyi olduğundan hareketle ivaz anlayışının temellendirilmesi gerektiğini vurgulayarak bu olguya işaret etmektedir. ${ }^{58}$ Çünkü elem vermenin Allah'a dönük bir faydası olmadığ1 gibi bu sayede O'nun bir çıkar elde etmesi de söz konusu değildir. Dolayısıyla acılar, hem acıya maruz kalan hem de acılara şahit olan için bir fayda taşımakta, bu yapisiyla da iyi olmaktadir. Ancak burada, sadece ivazın yeterli olup olmayacağı ya da ivazın yanında başka bir şartın da olması gerektiği Mu’tezile âlimlerince tartışılmıştır.

Ebu Ali'ye (ö. 303/915) göre Allah'1n sadece ivaz vermek için elemleri yaratması iyidir. Ebu Haşim (ö.321/933) ise ivazın yanına bir başka amacın varlığını daha ekler. $\mathrm{Bu}$ da ibret almaktır. ${ }^{59}$ Kâdî Abdulcebbar, Ebu Haşim’in görüşüne şu şekilde açılklk getirir. Allah, hiçbir acı yaşatmaksızın bir kimseye ivaz verecek kudrete sahiptir. Daha doğrusu ivaz vermek için illa da elemin varlığı şart değildir. Bu açıdan sadece ivaz vermek için elemin varllğı abes ve kabihtir. Çünkü menfaat sağlamanın yolu sadece elem değildir. Bu bakımdan eleme iyi nitelik kazandıran artı bir koşul olmalıdır. Bu ise elemin mükellef için ibret almaya arac1 olmasidir. ${ }^{60}$

Şu halde ivaz, kulun katlanmak zorunda olduğu acıları izah edebilmeyi sağlayan bir bedel teorisidir. Çünkü insanın çektiği elemler kendisi dışında bir başkası için ibret olacak ise bunun karşıllı̆ında kendisine bir bedel ödenmelidir. ${ }^{61}$ Örneğin özürlü biri kendi kendisine ibret olacak değildir. Böyle biri ancak başkaları için ibret vesilesidir. Bir başkasının faydası için katlanmak zorunda olduğu bu durumun bedeli kendisine ödenmelidir. Kâdî Abdulcebbar'a göre bu tür elemler, insanın iradesi dışında gerçekleşmektedir. Hiç kimse özürlü olmayı veya hastalı̆̆1 tercih etmiş değildir. Bu elemlere âdil bir karşllık takdir etmek, Allah'ın adaletinin bir gereğidir. Aksi halde insanların bir kısmına ibret olsun diye bazılarına acılar yaşatmak zulümdür. Mu’tezile teolojisinin Allah insan

\footnotetext{
58 İbn Melâhimî, Kitabu'l-fâik, fi-usûli'd-dîn, 324.

59 Kâdî Abdulcebbar, Șerbu'l-usûli'l-hamse, 493.

60 Kâdî Abdulcebbar, Șerhu'l-usûli'l-hamse, 493; Subhî, fì-İlmi'l-kelam, 2: 313,314.

61 Çelebi, "İvaz" 23: 499.
} 
ilişkisine dair en tavizsiz söylemi ise Allah'ın zulüm ve kötülükten münezzeh olmasıdır. ${ }^{62}$

Allah'ın asla kötü bir eylemde bulunmayacağı, çirkin işleri tercih etmeyeceği, kendisine vacip olan şeyleri yerine getirmede kendisiyle çelişmeyeceği ve yaptıklarının tamamının iyi olduğu adl ilkesinin zorunlu sonucudur. Kâdî Abdulcebbar bu hususu şu şekilde formüle etmektedir. Allah, kötü bir fiilin kötülügünü bilmekte, kötülükte bulunmaya ihtiyaç duymamakta ve kötülüğe ihtiyaç duymadığını da bilmektedir Bu vasıflara sahip olan bir varlığın kötülükte bulunması söz konusu değildir. ${ }^{63}$ Fakat burada şöyle bir sorunun akla gelmesi muhtemeldir. Allah kötülüğü biliyor ve yapmıyorsa niçin kötülük yapabilen varlıklar vardır? Bu sorunun Mu'tezile düşüncesinde en basit cevabı, dünyanın teklif yurdu olması ve bunun karşıllı̆ında bazı hakların garanti altına alınmasıdır. Doğru bir çıkarım olsa da burada Kâdî Abdulcebbar, Allah'ın zalime engel olmanın, zulme imkân tanımaktan daha tutarlı ve mazlum açısından daha âdil bir tasarruf olduğu düşüncesini kabul etmez. Çünkü böyle bir engelin teklifi geçersiz kılacağını düşünür. Allah, mükelleften kendi ihtiyarı ile zulümden kaçınmasını istemiştir. Bunun imkânı noktasında

\footnotetext{
Çelebi, "İvaz" 23: 499.
}

63 Kâdî Abdulcebbar, Şerbu'l-usûli'l-hamse, 301-302; Eş'arî, Allah'ın ahirette çocuklara azap etmesini aynı zamanda sonlu olan günah karşıllğında sonsuz bir ceza ile karşıllı vermesini O'nun adaleti gereği iyi kabul eder. Buna ilaveten O'nun inkâr edeceğini bildiği kimseyi başlangıçta yaratması, kafiri cennete mümini de cehenneme sokması halinde bunun Allah'ın adalete dayanan fiili olduğunu düşünür. Fakat böyle bir tercihte Allah'ın bulunmayacağını zira kâfirin daimi bir azapla cezalandırılacağı bilgisinin haber yoluyla bildirildiğini ve haberin mutlak doğru olduğunu ifade eder. Bk. Ebu'l-Hasen Alî b. İsmâîl b. Ebî Bişr İshâk b. Sâlim elEş'arî, Kitabu'l-lum'a fi'r-red' ebli'z-zeyği ve'l-bid', thk. Khamuda Gurabe (London: 1955), 116-117; Özellikle ilk dönem Eş’ariler Allah'ın küçük bir çocuğa azap etmesi halinde bunun adl olduğunu söylemişlerdir. O'nun her şeye kadir olması, böyle bir eylemde bulunmasını engelleyecek ve sorgulayacak bir gücün olmadığını gösterir. Bunun anlamı Allah, zulüm ve haksızlığa güç yetirebilir demektir. Hayyât, bu düşünceye Allah zulmetse ve yalan söylese de adil midir sorusunu sorar. Onların, Allah'ın yalan söylemesi ve zulmetmesinin muhal olduğu şeklinde cevap vereceklerini belirtir. $O$ da Allah'ın muhal olana kudretinin yeteceği şeklinde anlamsız bir sonuca ulaşmakla onları ilzam eder. Bk. Ebu'l-Huseyn Abdurrahîm b. Muhammed b. Osmân el-Hayyât, Kitabu'l-Intisâr alâ-İbni'r-Ravendìl-Mulbid, thk. H. S. Nyberg (Beyrut: 1993), 66. 
birey için fili yapabilecek ortam ve şartları hazırlama (temkîn) ve fiillerinde özgür birakmanın (tabliye) birlikteliği zorunludur. ${ }^{64}$ Dolayısıyla ivazın varllğını da temele alarak bu soruya verilebilecek en makul cevap, Allah'in zalimin tasarruflarına müdahale etmemektedir. Zulme engel olacak kudret ve iradeye sahip olmasına rağmen engel olmamış, zalimi fiilinde serbest bırakmıștır. Çünkü Allah'ın insanları iyilik ve kötülük edecek yapıda yaratması, onlar için eylemde bulunacakları donanımı sağlaması birbirleriyle ilişkili tasarruflarında özgür bırakması teklifin dolayısıyla ivazın vücub gerekçesini oluşturmaktadır.

Sonuç olarak ister ilahî kaynaklı elemler olsun isterse insanın neden olduğu zulümler olsun bunlara bir bedel takdir edilmiştir. İbn Metteveyh'e göre zalimin kötülüğü yanına kâr kalacaksa mazlumu böyle bir külfete maruz birakmanın izah edilebilir bir tarafı yoktur. Üstelik böylesi bir zorluk, kötü ve amaçsız bir davranıştır. ${ }^{65}$ Allah'ın bedelini ödemeyeceği veya ödetmeyeceği bir zararın varlığına ihtimal vermek ise Mu’tezilî düşüncede mümkün değildir. Bu bağlam Mu'tezile'nin, Allah, mazlumun hakkını bi-tamam teslim etmeyi üstlenmeseydi ona karşı işlenilen zulme asla müsaade etmezdi söylemi oldukça dikkat çekicidir. ${ }^{66}$ Ancak burada yanlış anlaşılmaması için şu hususun altı çizilmelidir. Dünyada kötülerin ve zalimin yaptıklarını, ahirete intikâl edecek fayda nedeniyle kanıksamak ve haklı tepkiler üretmemek ivazı anlamamak demektir. Çünkü insan, gücü ölçüsünde kötülüğe engel olmakla mükelleftir. Bunun karşıllı̆ı ise kalıcı mükâfat olan sevaptır. Sevap ise

\footnotetext{
Kâdî Abdulcebbar, el-Muğnî, 13: 417.

5 İbn Metteveyh, el-Mecmû, 3: 127.

66 İbn Melâhimî, Kitabu'l-fâik, fì-usûli'd-dîn, 324; Allah'1n temkin sebebiyle ivaz vermek zorunda olduğu görüşü eleştirilmiştir. Bunu eleştiri sadedinde Şerif Murtazâ bir örnek aktarır. Kılıcını düşmanla savaşması için bir başkasına veren ve bu kılıçla bi mümini öldüren kimseye öldürme imkânı verilmiştir. Bu kimseye kılıç verilmeseydi öldürme imkânı bulamayacaktı. Dolayısıyla bu anlayışa göre bu imkânı tanıma öldürme sonucu var olan ivazı gerekli kılmaktadır. Bu suça iştirak eden demirci ve kılıç satıcıları öldürme sonucu oluşan zararı tazmin etmeleri gerekir. Bununla birlikte bir elbiseyi gasbeden birinden elbisenin geri alınması veya bu kimsenin elbiseyi iade etmesine de gerek yoktur. Çünkü bunun bedeli tazmin edecek olan Allah'tır. Dolayısıyla Şerif Murtazâ'ya göre ivazın gerekliliği temkin ile ilişkilendirilemez. Bk. Şerif el-Murtazâ, ez-Zehîra, 242-243.
} 
bireyin özgür fiiline bağlı olduğundan değer ve fayda olarak ivazdan çok üstün bir değerdir.

\section{Zulüm-Elem İlişkisi}

Zulüm, en genel anlamıla "bir şeyi olması gereken yerin dışında başka bir yere koymak"tır. ${ }^{67}$ Hukukî ve dinî anlamılla zulüm, başkasının hakk1 olan şeyde haksızca tasarrufta bulunmak ve Allah'ın koyduğu sinırları çiğnemektir. ${ }^{68}$ Kâdî Abdulcebbar zulmü, malum veya zannî olsun kendisinde hiçbir fayda olmayan ve kendisiyle daha büyük bir zararın def edilme ihtimali de bulunmayan hak edilmemiss zarar olarak tanımlar. ${ }^{69}$ Buna göre içerisinde fayda taşımayan, oluşacak bir zarara engel olmayan, ceza gibi hak edilmeyen ve bu gerekçelere zan üzere de olsa sahip olmayan bir fiil zulümdür. ${ }^{70}$

Kâdî Abdulcebbar'ın düşüncesinde zulüm ile elemi farklı kılan en güçlü delil de bu noktadadır. Acı veren bir fiil, fayda sağlama veya zarara engel olma gayesi taşıyorsa iyidir. Zulüm ise fayda sağlama ve zarara engel olmaktan öte diğerine haksızca verilen zarar olduğu için kötü elemdir. ${ }^{71}$ Zulüm, ac1, keder veya her ikisine neden olan her türlü zarardır. Elemde ise bunların tamamı sürekli bir arada bulunmamaktadır. $^{72}$ Mu'tezile'ye göre birini yaralamak, öldürmek, haksızlık yapmak, malını gasp etmek gibi kötülüklerin zulüm olduğu zarurî olarak bilinmektedir. ${ }^{73}$ İbn Metteveyh'e göre kabihliği zarûrî olarak bilinen fillerin hem idrak boyutu hem de sabit hükümleri vardır. ${ }^{74}$ Buna

67 Seyyid Şerif Cürcânî, “'Zlm”, Mu'cemu'l-ta'rîfat, thk. Muhammed Sıddık el-Minşavî (Kahire: Dâru'l-Fâdıle, 2004), 121; Ebu'l Bekâ el-Kefevî, Eyyub b. Musa elHuseynî, "Zlm", el-Külliyyat, thk. Adnan Derviş-Muhammed el-Misrî (Beyrut: Müessesetü'r-Risâle 1992), 594; Kâdî, bu tanımın doğru bir tanım olmadığı düşüncesindedir. Çünkü ona göre yerli yerinde olmayan birçok şey zulüm olarak isimlendirilmez. Bk. Kâdî Abdulcebbar, el-Muğnî, 13: 271.

68 Cürcânî, “Zlm”, Mu'cemu'l-Ta'rifat, 121; Kefevî, “Zlm”, 594.

69 Kâdî Abdulcebbar, el-Muğnî, 13: 270.

70 Kâdî Abdulcebbar, el-Muğnî, 13: 270, 282, 283.

71 Kâdî Abdulcebbar, el-Muğnî, 13: 263.

72 Kâdî Abdulcebbar, el-Muğnî, 13: 270.

73 İbn Metteveyh, el-Mecmû, 3: 32.

74 İbn Metteveyh, el-Mecmû, 3: 33. 
göre zulüm ile insanın yaşadığı zarar ve üzüntü, ceza ve ivaz hükmünü gerekli kilmaktadır.

Diğer yönden zulmün faydaya dönüşümü imkânsız iken; elem ile fayda hak edilmektedir. Bu nedenle zulmün cezasi; elemin de bedeli söz konusudur. Zulüm ile birey, kendisine fayda sağlasa da aslî yapısı zarar odaklıdır. Bu nedenle kabih ve abestir. Buna karşın faydalandırma gayesi, elemi kötü ve anlamsız olmaktan çıkaran temel faktördür. ${ }^{75}$ Kâdî Abdulcebbar, fayda vermeyen, salt ac1 veren, hak edilmeyen, meşru bir hakk1 savunma olmayan her zararın kötü olduğunu aklın zarurî olarak bildiğini söylemektedir. Ona göre kötülüğün bilgisi akıllarda, zarûrî özler (mürekkeb zarûrî asıllar) olarak yer almaktadır. Bu bilgi aynı zamanda şeylerin niteliğine dair aklî bağıntıyı da sağlamaktadır. Daha doğrusu değerler bu tümel forma atıfla ahlakî hüküm kazanmaktadır. Örneğin, fayda ve zararı uzaklaştırma formundan uzak bir yalan, zorunlu olarak kötüdür. ${ }^{76} \mathrm{Bu}$ tümel kaideye göre zulmün değeri, kabih olmaktır. Çünkü zulüm, kendisinden bir faydanın elde edilmesi mümkün olmayan mahza zarardır. Kâdîya göre zulüm şeklinde olmasa dahi faydadan yoksun her tür zarar verme özünde kötüdür. Zarar ise fayda söz konusu olduğunda iyi değere dönüşebilmektedir. ${ }^{77}$

Diğer yönden Kâdî Abdulcebbar, zulmün salt zulüm olduğu için kötü olduğunu söyler ve zulmü sadece elem ve acıya sebep olduğu için kabih görmez. Çünkü elemlerin içerisinde faydalı olan ve zarara engel olanlar da vardır. ${ }^{78}$ Buna göre zulüm, bir başkasına yapılan kötü zarardır. Adl ise zulmün zıddı anlamıyla başkasına yapılan iyi zarardır. ${ }^{79} \mathrm{Bu}$ durumda Allah'ın fiilleri içerisinde zarar veren bulunsa dahi fayda ve adalet temel değer olduğundan tümü iyi niteliklidir. ${ }^{80}$ Öyleyse Mu'tezile'ye göre elemin kendisi kötü değildir. Çünkü elem acı ve 1stıraba neden olsa da hangi gaye için yapıldığı ve neyle sonuçlandığı önemlidir. İyi ve faydayı

\footnotetext{
Kâdî Abdulcebbar, el-Muğnî, 13: 283.

76 Kâdî Abdulcebbar, el-Muğnî, 13: 272.

77 Hanefî, Mine'l-akîde ila's-sevra, 3: 515.

78 Kâdî Abdulcebbar, el-Muğnî, 13: 261.

79 Kâdî Abdulcebbar, el-Muğnî, 6: 57.

80 Kâdî Abdulcebbar, el-Muğnî, 6: 57.
} 
sağlama amaciyla yapıliyorsa özünde iyidir. ${ }^{81}$ Kâdî̀ya göre elem zat ve cins itibarıyla da kötü ve zararlı değildir. Aksi halde elem cinsinden olan lezzetin de kötü olması gerekir. Böyle bir durumda da kötü olan fililin fâiliyle ilişkisini kurmak mümkün olmaz. Örneğin doğru, yalan cinsinden olduğu için yürümek, faydalı veya zararlı olan şeye doğru olsa dahi kötü olurdu. ${ }^{82}$ Buna göre elem iyi yönlere sahip ise ontolojik olarak zulüm ve kötü olamaz. Zulüm ise herhangi bir illete dayanmaksızın ontolojik olarak kötüdür. Kabihlik, zulüm için aslî bir unsur iken; elem için ârızî bir özelliktir. ${ }^{83}$

Zulüm ile elem arasındaki farklara değindikten sonra bilinmelidir ki Allah'ın en özel sıfatı adalettir. Zulme gücü yetmesine rağmen adaletli olma vasfi kötüyü yapmasına engel olmaktadır. Çünkü zulüm, noksan olan varlıkların bir özelliğidir. O'nun sonsuz kudreti ise sadece kemal olanı ve iyiyi ortaya çıkarmaktadır. ${ }^{84}$ Fakat burada şu tarz bir çıkarım ile karşılaşmak mümkündür. Fayda sağlamak için zarar vermek hasen ise bu durumda zulmün de hasen olması gerekir. Zira zulüm sayesinde Allah, mazluma fayda sağlamaktadır. Bu noktada Ebu Haşim, zararı iyi kılan unsurun fayda için yapıllyor olmasıyla ilişsilendirir. Fakat burada zalim, mazlumun ivazı hak etmesi kastıyla zulme yönelmemektedir. Zalim bizzat kendi menfaati için zulüm yapmakta iken zarar bir başkasının faydalanması için yapılmaktadır. Zulüm fiilinde böyle bir gayenin olması ise imkânsızdır. ${ }^{85}$

Sonuçta insanın elemi makulleştirmesi ve ruza ile kabul etmesi mümkün iken; zulme râzı olmak ve buna rıza göstermek imkân dâhilinde değildir. Üstelik insanın kabihe yönelik doğal bir nefreti söz konusudur.

81 Hulusi Arslan, Mu'tezile'ye Göre İyilik ve Kötülül-Husün ve Kubuh Problemi (Doktora Tezi, Erciyes Üniversitesi, 2000), 105.

82 Kâdî Abdulcebbar, el-Muğnî, 13: 262.

83 Mahsum Aytepe, Kâdî Abdulcebbar'da Lütuf Teorisi (Doktora Tezi, Ankara Üniversitesi, 2014), 247.

84 Bu konuda temelde iki görüș vardır. İlki, Allah zulme kadirdir. Zatı gereği kemal vasfina sahip olduğu için bunu yapmaz. Diğer görüş de Allah'ın zulme güç yetirmekle vasıflanamayacağı şeklindedir. Bk. Ahmed b. Yahya el-Murtazâ, el-Munye ve'l-emel, thk. Isâmuddîn Muhammed Ali (b.s.: 1985), 114.

85 Kâdî Abdulcebbar, el-Muğnî, 13: 285-286. 
Elem ise faydanın taşıyıcısı olarak içsel bir onay ve sabrı beraberinde getirmektedir. Fakat burada elemi oluşturan nedenlerin giderilmesi noktasında insana önemli görevler düşmektedir. Örneğin hastalıkların tedavisi için gerekli çalışma ve araştırmaları yapmak; mazluma yardım etmek için zulmü engel olacak güç ve otoriteye sahip olmak Müslümanın öncelikli görevidir.

\section{Zulmün Bedeli Olan İvazın Hükmü ve Keyfiyeti}

Zalimin mazluma verdiği zararı telafi etmeyi üstlenen Allah'tır. Çünkü zalim, bu hakkı kendi isteğiyle teslim etmeye yönelmez. Daha doğrusu karşılık olarak adil bir bedel takdir edemez. Mazlum da zalimden hakkını almaya güç yetiremez. Ayrıca mazlumun zalimden alacağı hakkın ne kadar olduğunu bilme imkânı da yoktur. Taraflar arasında terettüp eden hakların miktarları ve nasıl tazmin edileceği bilgisi sadece Allah'ın ilmindedir. Bu nedenle hakların hak sahibine eksiksiz ve adil bir taksimini yapacak olan da sadece Allah'tır. ${ }^{86}$

Mu'tezile genel olarak, ivazın acı ve sıkıntılara maruz kalana ödenmesini zorunlu (vâcip) kabul eder. İbn Melâhimî’ye göre bir kimse ivaz hakkı olduğunu ve çektiği 1stırapların bir ödülü olduğunu bilmese de ivaz hakk1 sabittir. Mükâfat ve ceza ile ivazı ayıran hususlardan biri de budur. Çünkü mükâfat ve cezayı hak eden biri bunların varlığını mutlaka bilmelidir. Bunun nedeni ise cezanın şartı içerisinde yerme ve küçümseme; mükâfatta yüceltme ve övme olmasıdır. Bir kimsede yüceltileceği bilgisi olmadan onu onure etmenin bir anlamı yoktur. Aynı şekilde kötü fiillerin yerileceği ve cezalandırılacağı bilgisi olmadan bireyi eyleme yöneltmek zordur. ${ }^{87}$ Ancak birey, ivaz hakk1 olduğunu bilmese dahi çektiği acıların bedeline hak kazanır. Baştan itibaren söylediğimiz üzere ivazın gerekçesi olan elem, bireyin kendi tercihi değildir. Tercih, iradenin bilinçli hareketi olduğundan bireyin özgür fiilleriyle ilintilidir. İvaz, insanın tercihi olmadığından bir yönüyle Allah'ın tedbîridir. Bu doğrultuda ivazın insan-insan ilişkisinde hak ediş koşullarına dair şu maddeler zikredilebilir.

86 İbn Metteveyh, el-Mecmû, 3: 128.

87 İbn Melâhimî, Kitabu'l-fâik, fì-usûli'd-dîn, 327. 
1. Birey, eylemiyle bir başkasına zarar vermiş olmalıdır. Çünkü bir kimsenin kendisine verdiği zarar ivaz hakkı oluşturmaz. Kişinin kendisine sağladığ1 fayda ile şükrü hak etmesi nasıl imkân dâhilinde değilse kendisine verdiği zararla ivazı hak etmesi de mümkün değildir. Hatta böyle biri kendisine verdiği zarar nedeniyle zalim olarak nitelenir. Üstelik bu eylem, kabih olduğundan fâili kınama ve cezayı da hak eder.

2. Başkasına verilen zarar ile oluşan ivaz hakkı, ivazın mazluma aktarılması yoluyla gerçekleşir. Yani zalimin var olan ivazı, mazluma aktarılır. Kâdî Abdulcebbar, sevabın aktarımını niteliği itibariyle (övgü ve yüceltmenin varlığı) mümkün görmez. Ancak ivaza tâzim ilişmediği için hak sahibine intikalini mümkün görür. ${ }^{88}$

3. Verilen zarar ile belirli bir fayda elde edilmiş ise bu ivaz yerine geçer. Ayrıca ilave bir ivaz hakkı söz konusu olmaz.

4. Zararı uzaklaştırmak için zarar verilmiş ise bu da ivaz hakkı oluşturmaz. ${ }^{89}$

İbn Melâhimîye göre mazlumun hak ettiği ivaz, zalimin verdiği zararın tazminidir. Bunun dünyevî karşıllğı bir suçun bedeli olan diyet ve tazminattır. Dolayısıyla dünyada oluşan zararın miktarınca tazmini nasıl gerekli ise mazlumun hak ettiği ivaz miktarı, zalimden alınarak mazluma aktarılır. Ancak yapmış olduğu zulüm ile kıyaslanmayacak bir karşıllı̆ı zalime ödetmek ise ona karşı yapılmış başka bir zulüm anlamına gelir. ${ }^{90}$ Şu hâlde hakların hak sahiplerine taksiminde adalet başat rol oynamaktadır. $\mathrm{Bu}$ açıdan hiç kimseye haksızlığın yapılmayacağ ${ }^{91}$ Kur'an'in da en aslî hukûkî söylemidir.

Fakat burada bilinmesi gereken husus, zalimin başkasına verdiği zararı karşlayacak miktarda ivaza sahip olması gerektiğidir. Aksi halde Allah'1n mazlumun hakk1 olan bedeli zalimden alarak ona ödemesi mümkün olmaz. Mu'tezile'ye göre böyle bir durumda yani ödeyecek ivaz1 olmayan birinin var olan sevapları yaptığ1 kötülüğü telafi etmek için

\footnotetext{
Kâdî Abdulcebbar, el-Muğnî, 13: 417-418.

39 Kâdî Abdulcebbar, el-Muğnî, 13: 418-419.

90 İbn Melâhimî, Kitabu'l-fâike fì-usûli'd-dîn, 327.

91 el-Enbiyâ 21/47; Yasîn 36/54.
} 
devreye girer. Dolayısıla zalimin sevaplarından alınıp zarara uğrayana aktarilarak bu zarar giderilmiş olur. Böylece sevap, fayda sağlama konumunda ivazın yerine geçer. ${ }^{92}$ Yani zalimin iyilikleriyle hak etmiş olduğu menfaatlerden zarar miktarı eksiltilerek mazluma aktarılır. ${ }^{93}$ Burada dikkati çeken husus, sevabın naklinden ziyade fayda aktarımının söz konusu olduğudur. Çünkü sevabı düşürecek veya eksiltecek olan ivaz değil, sadece cezadır. Sevab ise vacibi yapıp kabihten kaçınmakla övgü ve yüceltmenin bitiştiği hak edilmiş faydadır. Bu açıdan İbn Metteveyh'e göre dünyevî koşullar içerisinde hak edilen bir övgünün başkasına nakli nasıl imkânsız ise sevabın da aynı şekilde bir başkasına nakli imkânsızdır. Ona göre haber yoluyla bildirilen iyilikler (basenât) ve kötülüklerin (seyyiât) nakledileceği bilgisi ivaz olarak anlaşılmalıdır. Buna göre taat veya masiyetin ötekine aktarımı söz konusu değildir. ${ }^{94}$ Öyleyse ivaz ile sevaptan eksiltmek mümkün olmadığına göre sevabın mevcut faydası mazluma aktarilır.

Bunun yanında Kâdî Abdulcebbar, ivaza sahip olmadan ölen birine Allah'ın gerektiği kadar tefaddulde bulunup sonra bu miktarı alarak mazluma ivaz olarak aktaracağı görüşünü de irdeler. $O$, bu görüşü makulleştirmek için beşerî tecrübeden yararlanıldığını söyler. Nitekim borcu olan birine borcunu ödemesi için belli bir miktar para verilebilir. Allah da hak etmeyen birine diğerinin hakkını ödemesi için tefaddulen iyilikte bulunabilir. Kâdî Abdulcebbar, öncelikle böyle bir tasarrufun 'intisâf a aykırı bulduğu için kabul edilemeyeceğini söyler. İntisâf, anlamı gereği mazlumun zalimden hakkı olanı almasıdır. Yoksa Allah'ın zalime ihsan ettiği faydayı, mazlumun ivaz olarak alması değildir. Kâdî, bu meseleyi bir örnekle de izah eder. İki kişi arasında cereyan eden bir davada hâkimin takip edeceği hukûkî işlem, hakkın zalimden alınarak haklı olana teslimidir. Hâkimin kendi cebinden zararı tazmin etmesi ise intisaf değildir. Hatta bu durum zalime verilen bir ödül niteliği taşımaktadır. ${ }^{95}$

\footnotetext{
Kâdî Abdulcebbar, el-Muğnî, 13: 450; İbn Metteveyh, el-Mecmû, 3: 128.

İbn Melâhimî, Kitabu'l-fâik, fî̀-usûli'd-dîn, 324.

İbn Metteveyh, el-Mecmû, 3: 128.

95 Kâdî Abdulcabbar, Șerbu'l-usûli'l-bamse, 505; el-Muğnî, 13: 459-460.
} 
Ayrıca intisâf, vacip bir fiil iken; tefaddul vacip değildir. Çünkü Allah, tefaddulen fayda sağlamayı tercih etmeyebilir. Zira tefaddul, mümkin bir fiil olarak fâilin irade ve ihtiyan ile doğrudan ilişkilidir. Fakat ivaz hakkı olan kimseye ivazın verilmesi vaciptir. Vacip ise bir tercih değil, yapılmadığında yergiyi gerektiren zorunlu bir fiildir. Yergi ile Allah'ın fiilinin bağdaşması ise imkân dışıdır. Bunun dışında Ebu Haşim’e göre Allah, ivaza sahip olmadan öleceğini bildiği kimseye imkân vermeyerek (temkîn) zulmüne engel olabilir veya ivaz hakkına sahip olarak öleceğini bildiği birine zulüm imkânı verebilir. ${ }^{96}$ Böyle birine zulüm imkânı vermek ona göre kötü bir eylemdir. O, meseleye intisâf bağlamında yaklaşır. Ona göre hakların birebir teslimini mümkün kılacak nesnel bir ölçüt olmalıdır. Aksi halde bir hak kaybının yaşanması, adaleti zedelediğinden kötünün var olması demektir. ${ }^{97}$ Buna göre Ebu Haşim’in düşüncesinde şöyle bir sonuç ortaya çıkmaktadır. Bir kimse zulüm fiili işliyorsa bunu karşılayacak oranda ivaza sahip demektir. Hatta zulmünü ne kadar artırırsa o oranda ivaza da sahip anlamina gelmektedir. İbn Metteveyh ise Ebu Haşim'in bu sonucunu tartışmaz. Sadece ivazı olmayan birine zulmetme imkânının verilmeyeceğini söyleyerek meseleyi çözümsüz bırakır. ${ }^{98}$ Bu sebeple tefaddulü alternatif bir çözüm olarak da ileri sürmez. Çünkü tefaddulun isteğe bağlı olması, yokluğu halinde mazlumun hakkını yine yitirmesi anlamına gelmektedir. ${ }^{99}$ Görüldüğü üzere Allah'ın zalime tefaddulda bulunacağ1 veya ivazı olmayan birine zulmetme firsatı vermeyeceği düşüncesi pek tutarlı görülmemektedir.

Bu doğrultuda İbn Melâhimi, öncelikle cezanın, zalimin işlediği günahların karşıllğ1 olduğunu vurgular. Çünkü zalim, kötü fiiliyle cezalandırılmayı hak etmiştir. Şu hâlde ona göre mazlumun intikamı, Allah'ın zalime zulmü ve günahları nedeniyle verdiği cezadır. Fakat burada başka bir problem daha ortaya çıkmaktadır. Allah'ın zalime ceza verip mazluma ivaz vermemesi durumunda zalimin yaptığ1 zulüm mazlum için ilave bir zarara dönüşmekte midir? Çünkü bu durumda mazlum, zarara uğramış, tahammül etmek zorunda olduğu zulüm

\footnotetext{
96 Tûsi, Tembîdu'l-usûl, 351; Ayrica bk. İbn Metteveyh, el-Mecmû, 3: 116.

97 Tûsi, Tembîdu'l-usûl, s. 351-352; İbn Metteveyh, el-Mecmû, 3: 116.

98 İbn Metteveyh, el-Mecmû, 3: 117.

99 İbn Metteveyh, el-Mecmû, 3: 117.
} 
karşıllğında bir bedel de elde edememiştir. Bu ise mazlum için ayrı bir zulüm anlamina gelmektedir. ${ }^{100}$ Ancak bilinmelidir ki zalimin hak ettiği cezayla yüzleşmesi, mazluma verilen bir ödül niteliği taşımaktadır. Mazlumun elde edeceği ziyade faydalar ile zalimin zulmünün yanına kâr kalmadığı bilgisi kendisi adına bir fayda anlamına gelmektedir.

Bundan başka şöyle bir soru da akla gelebilmektedir. Kâfirin dünyada maruz kaldığı acıların bedelini yaşarken alamaması halinde durum nasıl olacaktır? İbni Melâhimî, Allah'ın hak ettikleri cezadan bir parça düşüreceğini söyler. Bu düşen kısım, hak ettikleri ivazın karşıllı̆̆ıdır. $\mathrm{O}$, bir kimseye ivaz vermekle, bir miktar zararı düşürmek arasında fark olmadığı düşüncesindedir. ${ }^{101}$ Kâdî Abdulcebbar da lezzet vermekle elemden vazgeçmeyi aynı konumda olan iki fayda olarak anlar. Çünkü akıllı biri lezzet yerine acının giderilmesini seçebilir. Yine acılara tahammül göstererek lezzet elde etmeyi isteyebilir. ${ }^{102}$ Benzer şekilde Allah, fasığın itaati ile hak ettiği sevap miktarını cezasından düşer ve bu sayede hak ettiği ceza hafiflemiş olur. ${ }^{103}$

Bundan başka Kâdî Abdulcebbar, zalimin cezası ile ivazının birlikteliğinin mümkün olduğunu düşünür. İvaz, zalimden alınarak mazluma aktarılabilir veya var olan ivazından zalim yararlanabilir. Hakkı olan ivaz ile de azabında bir hafifleme oluşabilir. İvazdan yararlanma hakk1 ise kendi üzerindeki hakların hak sahiplerine tesliminden sonra mümkündür. ${ }^{104}$ Ancak Allah, aklen, cehennem ehli olan birinin hak ettiği ivazı dünyada iken veya cehenneme girmeden verebilir. ${ }^{105}$ Cenneti hak eden birine ise ivazın ulaşması hak ettiği mükâfatla birlikte ziyade tefaddul ile gerçekleşir. ${ }^{106}$ Bununla birlikte ivazın kesintili olması mükâfat ehlinde bir üzüntü meydana getirmez. Kâdî Abdulcebbar'a göre haber, ahirette kâfire ulaşacak bir faydanın veya sevincin olmadığını

\footnotetext{
100 İbn Melâhimî, Kitabu'l-fâik fì-usûli'd-dîn, 325.

101 İbn Melâhimî, Kitabu'l-fäike fî-usûli'd-dîn, 327-328.

102 Kâdî Abdulcebbar, el-Muğnî, 13: 445.

103 Kâdî Abdulcebbar, el-Muğnî, 13: 446.

104 İbn Metteveyh, el-Mecmû, 3: 118.

105 Kâdî Abdulcebbar, el-Muğnî, 13: 446; İbn Metteveyh, el-Mecmû, 3: 118.

106 Kâdî Abdulcebbar, el-Muğnî, 13: 445; Şerbu'l-usûli'l-bamse, 340.
} 
bildirmektedir. Aksine onların azap, keder ve hüzün içerisinde olacaklarını ifade etmektedir. ${ }^{107} \mathrm{O}$ halde kâfir, hak ettiği ivaza nasıl ulaşacaktır? Kâdî̀ya göre cezadan bir parça elimine etme cehennem ehline has bir fayda iken; ziyade lezzetleri hak etme cennet ehline özel bir faydadır. ${ }^{108} \mathrm{Bu}$ bakımdan cehennem ehli olan birinin hak ettiği ivaz salt menfaat olamaz. Menfaat yerine geçen azapta tahfif, yöntem olarak tercih edilebilir. Aklen de fayda ile zarara engel olmanın benzer lezzet olduğu bilinen bir husustur. ${ }^{109}$ Fakat Kâdî Abdulcebbar, azaba yapılan bu müdahale ile bir sevinç ve rahatın meydana gelmesini uzak görür. ${ }^{110}$ Çünkü ahirette cezayı hak eden günahkâr ve kâfir için salt fayda imkânsızdır. Kâdî, burada önemli bir şartı zikreder. Azapta hafifletmenin şartı cehennem ehli olmaktır. Lezzetin hak edilme koşulu ise cezayı hak etmemektir. ${ }^{111}$ Hatta cezay 1 hak eden mevcut sevab1 ile de fayda elde edemez. Çünkü ceza, ivazı düşürmese de sevabı düşürür. ${ }^{112}$ Kâdî̀ya göre fâsığın işlediği günah, taatlerini düşürse de hak ettiği ivazı düşüremez. ${ }^{113}$ Bu bağlamda o, cezanın ivazı düşürmeyişini iki sebebe dayandırır.

1. İvaz tâzim ve tebcîl yoluyla hak edilmez.

2. İvaz daimî değildir. Bu iki nedene bağlı olarak cezayı hak etmek, ivaza engel değildir. Çünkü ceza, ivaza zıt bir değer değildir. ${ }^{114}$ Kâdî Abdulcebbar, ceza gibi ivazın sürekli bir fayda olmadığı kesintili olduğunu özellikle vurgular. Buna sebep de ivazın kesintili olması bir rahatlık ve lezzetin varlığına engel oluşturacak olmasıdır. ${ }^{115}$

Ebu Ali ise hak edilen cezanın ivazı düşüreceği görüşündedir. Bu durumda Kâdî Abdulcebbar, şöyle bir soru yöneltir. Cezayı hak eden biri, yaptığı zulüm ile mazlumun hakkını nasıl teslim edecektir? Bu soruya

\footnotetext{
107 Kâdî Abdulcebbar, el-Muğnî, 13: 445; İbn Metteveyh, el-Mecmû, 3: 118.

108 Kâdî Abdulcebbar, el-Muğnî, 13: 446.

109 Kâdî Abdulcebbar, el-Muğnî, 13: 445, 451.

110 Kâdî Abdulcebbar, el-Muğnî, 13: 446.

111 Kâdî Abdulcebbar, el-Muğnî, 13: 446.

112 Kâdî Abdulcebbar, el-Muğnî, 13: 448.

113 Kâdî Abdulcebbar, el-Muğnî, 13: 446.

114 Kâdî Abdulcebbar, el-Muğnî, 13: 446.

115 Kâdî Abdulcebbar, el-Muğnî, 13: 447.
} 
Ebu Ali'nin ilave açıklaması ile cevap verir. Ebu Ali'ye göre mazlumun hakk1 olan ivaz, zalimin hak ettiği ceza ile düşmez. Zalimin hak ettiği ceza, kendi hakkı olan ivazı düşürür. Mazlumun ivazı sabit olduğundan ivazın nakli ile hak sabit olur. Ona göre zalimin hak ettiği ivaz bir başkasının hakkı değil ise ceza ile düşer. ${ }^{116} \mathrm{Ebu}$ Ali, burada istisnai bir kaide ortaya koymuştur. Buna göre zalim, cehennem ehli ise mazlumun hakkı olan ivazı ondan alabilmesinin yolu ivazın düşmemesidir. ${ }^{117}$ Kâdî Abdulcebbar, Ebu Ali ile bu konuda hemfikir olduğunu vurgular. Görüş ayrılığ1 olarak Ebu Ali'nin cezanın ivazı düşüreceği iddiasına karşın o, cezadan bir parçanın düşürüleceğini ileri sürmektedir. ${ }^{118}$ Şu halde ivaz, faydanın hak sahibine ulaştırılmasıdır. Kâfir veya mümin hak eden herkese hak ettiği bir şekilde ulaştırılmalıdır. Söz konusu hakkın ulaştırılması noktasında herhangi bir ihmal veya iltimas caiz değildir. ${ }^{119}$

Burada mazlumun hakkını dünyada peşinen alması ise tartışılan bir başka konudur. Bu görüşte nasıl ki bir babanın evlatları arasında olan hak ihlallerini dünyada halletmesi gerekiyorsa Allah da dünyada mazlumun hakkını tabiri câizse zalime ödetmelidir. Bu hususta Kâdî Abdulcebbar hakkın ertelenebileceği kanaatini taşır. Bu örnek üzerinden kendi görüşünü ortaya koyar. Ona göre baba çocuklardan birinin diğeri üzerinde hakkı olduğunu bilir ve o anda bu hakkı ifa etmeye kalktığında çocukları arasında huzursuzluk çıkacağı endişesini taşırsa bunu ertelemesi gerekir. Allah'ın da dünyada iken mazlumun hakkını peşinen almasında bir yarar olmadığını bildiğine göre bunu ertelemesi vaciptir. ${ }^{120}$

Anlaşıldığı kadarıyla ivaz bir başkası ile olan ilişkinin sonucunda hak edilir. Bu ilişkide taraflardan biri diğerine haksızca zarar vermiş ise ivaz ödemekle bu hukuksuzluğu tazmin eder. Burada önemli olan herhangi bir zorlama olmadan fiilin meydana gelmesi ve Allah'1n mubah kıldığı veya ibadet olarak emrettiği bir eylem olmamasıdır. Örneğin bir kimse bir başkasını zarar vermeye zorluyorsa (ilcâ) burada ivazın alınacağı

116 Kâdî Abdulcebbar, el-Muğnî, 13: 447.

117 Orhan Şener Koloğlu, Cübbâileriin Kelam Sistemi (İstanbul: İsam Yayınları, 2011), 452.

118 Kâdî Abdulcebbar, el-Muğnî, 13: 447.

119 Kâdî Abdulcebbar, el-Muğnî, 13: 446.

120 Kâdî Abdulcebbar, el-Muğnî, 13: 448. 
kimse doğrudan zarar veren değil, zarara zorlayan kimsedir. Çünkü bir fiile zorlamak, o fiili bizzat yapmak gibidir. Yine Allah'in ibadet olarak yapılmasını emrettiği şeylerin ivazını ödeyecek olan da kendisidir. ${ }^{121}$ Yine bir kimse bir başkasının ölümüne sebep olsa ivazı ödeyecek olan Allah değil, sebep olandır. Örneğin bir insanı haksız yere öldüren, bir çocuğu soğukta kapının önüne koyup ölümüne sebep olan veya bir hayvanın sırtına çok fazla yük yükleyip acı çekmesine neden olan kimse ivaz ödemek zorundadır. Çünkü burada mazlumun dünyada elde edeceği faydanın zalim tarafindan engellenmesi söz konusudur. Bunun tazmini ise ahirette mazluma ivazın nakledilecek olmasıdır. Netice itibarıyla kulların fiili sonucunda gerçekleşen acıların bedelini ödeyecek olan Allah değildir. ${ }^{122}$

\section{Zulme Maruz Kalanın İvaz Hakkından Vazgeçmesi}

Ebu Haşim ve Kâdî Abdulcebbar ivazın dünyada verilebileceği gibi ahirete de ertelenebileceğini kabul ederken; Ebu Ali, sevaba kiyasla ancak ahirette verilebileceğini ileri sürer. ${ }^{123} \mathrm{Bu}$ konuda Kâdî, ivazın dünyada peşinen alınabileceği veya ahirete ertelenebileceği düşüncesini irdeler. Ona göre dünyada iken ivazın ifası veya iskatı mümkündür. Çünkü bir kimse hakkı olanı isteyebildiği gibi hibe veya ibrâ yoluyla alacağından vazgeçebilir. Örneğin bir borcun varlı̆̆ı, borçluya ödemeyi zorunlu kıldığı gibi birinin elbisesini parçalayan kimseye de bedelini ödemek zorunlu olmaktadır. Fakat burada bedelin alınmayarak söz konusu haktan vazgeçilmesi (iskat) yine imkân dâhilindedir. ${ }^{124}$

Kâdî Abdulcebbar, Allah'a vacip olan ivaz ile beşerî zeminde hukuka dayalı ivazın ahirete erteleneceğini söyler. Bu ivazların dünyada istenilmesini veya hibe ve ibrâ yoluyla düşmesini doğru bulmaz. Çünkü Kâdî'nın düşüncesinde miktarını yalnızca Allah'ın bildiği ve hak sahibine ulaştırma kudretine sahip olanın sadece kendisinin olduğu ivazlar vardır. Allah'in tedbîr hukukuna riayet ederek insanlar arası hukûkî ilişkileri

121 Şerif Murtazâ, eq-Zehîra, 246

122 Kâdî Abdulcebbar, el-Muğnî, 13: 378; Şerif Mutazâ, ę-Zebîra, 247.

123 Abdülkerim Osman, Nazariyyetü't-teklif-ârâu'l-kâdî-abdilcabbari'l-kelâmiyye, (Beyrut: 1971), 474.

124 Kâdî Abdulcebbar, el-Muğnî, 13: 453. 
düzenleyecek olması ibrâ veya hibe yolunu kapatmaktadır. Bu nedenle temini mümkün olmayan hakların ahiretin hukukuna ertelenmesi ona göre daha doğrudur. ${ }^{125}$

İbn Melâhimî ise meseleye Allah'ın üzerine ve kulun üzerine vacip olan ivaz ayrımı yaparak yaklaşır. Ona göre Allah'ın ödemeyi taahhüt ettiği ivazın düşmesi mümkün değildir. Bu ivazın dünyada istenmesi de imkân dışıdır. Çünkü Allah hakkına terettüb eden ivaz, kulun ödemesi gereken ivazdan farklıdır. Mazlum, zalim üzerindeki hakkı olan ivazı düşürebilir. Üstelik bu ivazın düşmesi zalimin yararınadır. Yani mazlum alacağı olan ivazdan vazgeçerek zalime fayda sağlayabilir. ${ }^{126}$ İbni Melâhimîye göre ivaz hakkına sahip birinin hakkı olan miktarı ayrıntısıyla bilmesine de gerek yoktur. Böyle bir hakka sahip olduğunun bilincinde olması yeterlidir. Böyle biri sadece hakk1 olanı talep etmekle yetinebilir. Allah'1n kendisine vacip olan ivazı düşürmesi ise abes ve kabihtir. ${ }^{127}$ Çünkü kulun hakkı olan ivazı düşürmede Allah'ın hiçbir menfaati yoktur. Öyle ki Allah, faydalanmak ve menfaat elde etmekten de uzaktır. ${ }^{128}$

Sonuç olarak Allah'ın hastalık, musibet ve üzüntüler vermesiyle oluşan elemin hakkı olan ivaz ahirete ertelenebilir. Yine zalim ile mazlum arasındaki hakkın miktar ve etkisini en iyi bilen O'dur. Bu tür hakların hak sahiplerine iadesi Allah için bağlayıcılık doğurur. Bu yönüyle ivazın ahirete ertelenmesi daha makuldür. Ancak dünyada hukukun müdahalesiyle veya bireyler arası anlaşma ile çözülecek durumlar tecrübe edilmektedir. İnsanın zulüm ile kendisine sağladığı haksız menfaatlerin ahirete ertelenmesi Mu’tezilî düşüncede zorunlu görünmektedir. Çünkü her zaman yasal olarak veya anlaşma ile hakların mutlak tesisi gerçekleşemeyebilir. Böyle bir durumda Allah'ın hak sahiplerine tedbîr uygulaması zorunlu olmaktadır. Hatta Kâdî̀ya göre Allah, kendi üzerine vacip olan hakları düşürmeme noktasında zorlanmıştır (mülce). ${ }^{129}$

125 Kâdî Abdulcebbar, el-Muğnî, 13: 453.

126 Kâdî Abdulcebbar, el-Muğnî, 13: 453; İbn Melâhimî, Kitabu'l-fâike fî̀-usûli'd-dîn, 328.

127 İbn Melâhimî, Kitabu'l-fâik, fì-usûli'd-dîn, 328.

128 Kâdî Abdulcebbar, el-Muğnî, 13: 453; İbn Melâhimî, Kitabu'l-fầk fì-usûli'd-dîn, 328.

129 Kâdî Abdulcebbar, el-Muğnî, 13: 454. 
Esasında dünyada helal ve ahlakî olana öncelik verildiğinde insanlar arası hak ihlallerinin büyük oranda engelleneceği malumdur.

\section{Hak Edilen İvazın Ceza (İkab) ile Düşmesi}

Câhız, dünya ve ahirette iki tür cezanın olduğunu söyler. İlkinde başa gelen ceza bir yönüyle felaket diğer yönüyle ise nimettir. Çünkü yaşanan ac1 ve üzüntü sonuçta bir nimete dönüşüyorsa iyidir. Dünyada yaşanan acı ve hüzünler günah işlemeye direnç oluşturan bir engelleyici; diğer insanlar için ise ibret alma vesilesidir. Bu yönüyle iyi ve faydalıdır. Ceza ise sırf felaket, zarar ve üzüntüdür. İkincisinde başa gelecek olan bir ihtimalin söz konusu olmadığı bir yer olarak bu cezadan kurtulmanın yolu yoktur. $\mathrm{Bu}$ 1stırap ve cezanın nimete ve sevince dönüşmesi de mümkün değildir. ${ }^{130}$ Ancak hakkında cezanın kesinleştiği biri aynı zamanda ivaz hakkına sahip olabilir. Bu durumda cezanın ikaba etkisi ne şekilde olacaktır?

Kâdî Abdulcebbar'a göre hak edilen ivaz, hak edilen ceza ile düşmez. İvaz, bu özelliğiyle mükâfattan ayrılır. Çünkü ihbat kuralı gereği mükâfat ve ceza arasında bir oranlama yapilır ve fazla olan az olanı düşürür. Fakat ivazın, ceza ile düşmesi mümkün değildir. Dolayısıyla ihbat kuralı, ivaz için geçerli değildir. ${ }^{131}$ Çünkü ivaz, tâzim yoluyla hak edilen bir değer değildir. Buna sebep ivaz için övgü ve yüceltmenin vacib olmamasıdır. Bunun yanında mükâfat ve ceza daimi olarak hak edilmekte ve her ikisinin birlikteliği veya dönüşümlü hak edilmesi mümkün gözükmemektedir. Bunun aksine Kâdî, ivazın kesintili ve sonlu bir fayda olduğunu söylemektedir. Aynı zamanda ivaz, cezanın zıddı değildir. Bu nedenle ona göre cezayı hak eden birinin ivazı hak etmesi mümkündür. Şu hâlde hak edilen ceza, diğer hak edilen ivazı düşüremez. ${ }^{132}$ Kâdî̀ya göre şahid âlemde de ceza ve kınamayı hak eden birinin hakkı olan bedeli hak etmesine engel olacak bir şey yoktur. Fakat kınamay1 hak eden birinin övülmesi iyi değildir. ${ }^{133}$

130 Câhız, Kitabu'l-Hayevân, (1943), 5: 100.

131 Kâdî Abdulcebbar, el-Muğnî, 13: 446.

132 Kâdî Abdulcebbar, el-Muğnî, 13: 446.

133 Kâdî Abdulcebbar, el-Muğnî, 13: 447. 
Burada şöyle bir soru akla gelebilir. Ceza ivazı düşürmüyorsa ivazın hak sahibine takdimi durumunda bu kişi hem cezalandırılan hem de faydalandırılan konumunda mı olacaktır? Kâdî Abdulcabbar'a göre ivazın aynılla bir kimseye verileceği söylenemez. Çünkü ivaz bir lezzet/faydadır. Bunun yerine geçecek başka bir değer hak edene verilebilir. Bu da daha önce geçtiği üzere azabında bir hafifletmeyle mümkün olmaktadır. Ancak bu müdahale ile cezalandırılanın rahat ve huzura kavuşması imkân dışıdır. ${ }^{134}$ Zira sonlu faydanın daimî bir lezzete imkân tanıması mümkün değildir. Kâdî Abdulcebbar'ın aksine Ebu Ali ise hak edilen cezanın ivazı düşüreceği kanaatindedir. Fakat Kâdî, kendi düşüncesinin daha doğru olduğunu söyler ve Ebu Ali'ye katılmaz. ${ }^{135}$ Başka bir ihtilaf ise bir başkasını hakkı olmayan ivazlar konusundadır. Bu durumda Ebu Ali'ye göre başkasının hakkıyla ilgisi olmayan ivazlar ceza ile düşer. Kâdî Abdulcebbar ise cezadan bir parça eksiltmeyle ivazın verileceği düşüncesindedir. ${ }^{136}$

\section{8. İvazın Daimi veya Sonlu Olması}

İvazın daimi olup olmadığı Mu’tezili âlimler tarafından tartısılan konular arasındadır. Basra'dan Ebu'l Huzeyl (ö.235/849) ile Belhî Abbad b. Süleyman (ö.250/864) gibi bazı Bağdat ekolu müntesipleri ivazın daimi olduğunu kabul etmişlerdir. Ebu Haşim, Kâdî Abdulcebbar ve Basra okulunun büyük çoğunluğu ivazın sonlu olduğunu söylemişlerdir. ${ }^{137} \mathrm{Bu}$ konuda Ebu Ali’nin iki farklı görüşte olduğu nakledilir. Onun ilk görüşü, ivazın sürekli olarak hak edileceği yönündedir. Diğer görüşte ise Ebu Ali, bu düşüncesinden vazgeçerek ivazın sonlu olduğunu söylemiştir. ${ }^{138}$ Ebu Haşim ise ivazın sonlu olarak hak edileceği kanaatini taşır. Ebu Ali’nin ilk düşüncesi şu şekilde izah edilmiştir. Ona göre ivazın sonlu olarak hak edilmesi halinde oluşan kesinti, bir başka ivazın varlığını gerektirir. Çünkü hak edilen ivazda yaşanan kesinti sebebiyle üzüntü meydana gelmiştir.

\footnotetext{
134 Kâdî Abdulcebbar, el-Muğnî, 13: 447.

135 Kâdî Abdulcebbar, el-Muğnî, 13: 447.

136 Kâdî Abdulcebbar, el-Muğnî, 13: 447.

137 Abdülkerim Osman, Nazariyyetü't-Teklif, 473.

138 Kâdî Abdulcebbar, el-Muğnî, 13: 433.
} 
Bunu telafi etmek için bir başka ivaza ihtiyaç vardır. Bu bakımdan ivaz, daimi bir şekilde hak edilmelidir. ${ }^{139}$

Ebu Ali, ivazın sürekli olmasını başka bir delille şöyle açıklar. Ona göre ivaz, kesintili olarak hak edilseydi dünyada işlenen suçlara ödenen tazminat ve diyetler gibi tek bir seferde eleme maruz kalana ulaşırdı. İbn Melâhimî böylesi bir iddianın ivazın sürekliliğine delil kılınamayacağını söyler. Çünkü böyle bir durumda ivazı hak eden farklı zamanlarda ivazın kendisine verilmesini talep edebilir. Zamana yayılan faydalar için insan elemi seçebilir. İbn Melâhimî, bunu bir örnekle izah eder. Bir kimseye uzun yıllar krallık verileceği fakat bunun karşllı̆ı̆nda belli bir süre acılara tahammül göstermesi gerektiği söylense bu kimse sonlu olan acılara katlanmayı tercih eder. Her ne kadar burada elde edeceği menfaat süreli de olsa sonlu elemlere ve sıkıntılara katlanmayı seçer. ${ }^{140}$ Elemler karşıllı̆ında hak edilen ivazın zamana yayılabilmesi Ebu Ali'nin süreklilik iddiasını geçersiz kılmaktadır. Yani tek bir seferde ivazın hak edene ulaştırılması zorunlu olurdu iddiası bu örnek durum üzerinden çürütülmeye çalışlmıştır.

Ebu Haşim'e göre ak1llı her kimse sonlu ve sınırlı bir fayda elde etmek için süreli birtakım acılara katlanmayı iyi kabul eder. Örneğin insanlar kazanç sağlamak, geçimlerini ve menfaatlerini temin etmek için uzun yolculuklara çıkarlar. Yolun verdiği sıkıntı ve külfete katlanırlar. Bu da göstermektedir ki sonlu olan büyük menfaatler için sonlu olan acılara insan katlanabilmektedir. Bu nedenle elemlerin iyi olmasının şartı ivazın sürekli olması değildir. ${ }^{141}$ Diğer yönden ivaz, dünyevî hukukta tazminat ve diyete benzetilmiştir. Dünyada bunların daimî olarak hak edilmedikleri malumdur. Örneğin bir kimsenin elbisesini yırtan sadece elbisenin kendisini veya bedelini öder. Yoksa her gün yeni bir elbise vermez. ${ }^{142}$

Kâdî Abdulcebbar, ivazın kesintili olması halinde bireyde bir elem ve üzüntünün oluşmasına değinir. Ona göre birey, kendisine verilecek

139 Kâdî Abdulcebbar, Şerbu'l-usûli'l-hamse, 494; İbn Melâhimî, Kitabu'l-fâike fî̀-usûli'd-dîn, 326.

140 İbn Melâhimî, Kitabu'l-fäik, fì-usûli'd-dîn, 326.

141 İbn Melâhimî, Kitabu'l-fâik fì-usûli'd-dîn, 326.

142 Kâdî Abdulcebbar, Şerhu'l-usûli'l-hamse, 494-495. 
olan ivazın miktarını bilmektedir. Hakkı olan ivaz hatta fazlası kendisine verilir sonra kesinti gerçekleşir ise bununla üzüntü ve ac1 meydana gelmez. ${ }^{143}$ İvazın sonlu olduğu bilgisi, ayrıca bir ivazın varlığını da gerektirmemektedir. Zira ahirette kalıcı olan mükâfat ve cezanın dışında başka bir zarar veya fayda söz konusu değildir.

Ebu Haşim'in ivazın sürekli olmadığı düşüncesinde olmasının bir başka gerekçesi ivaz ile sevabın eşitlenme durumudur. Sevab kişiye ulaşacak en büyük faydadır. Bu faydanın mükellefe ulaşmasının yolu sadece tekliftir. İvaz, daimi olarak hak edilirse bu durumda sevaba benzer miktarda faydanın sağlanması demektir. Bu ise sevabi tek hak etme yöntemi olan teklifi emre alternatif bir seçeneğin varlığ1 anlamına gelir. Bu durumda Allah, inkâr edeceğini bildiği kimseye acılar yaşatıp ivaz ile sonsuz fayda sağlayabilir. Bu şekilde fayda sağlama imkânı varken kâfirin teklife muhatap olması ise kötü bir hale dönüşür. Daha doğrusu kâfir ve günahkâr, ameliyle hak edemediği faydayı ivaz ile hak edebilir. Böyle bir ihtimal Mu'tezile'nin istihkak kanununa aykırı bir durumdur. Bu nedenle ivaz sonlu olmalıdır. ${ }^{144}$

\section{Sonuç}

Dünya, insana değişik acı ve felaketlerin yaşanabildiği bir varoluş biçimidir. Dolayısıyla her insan yeri, zamanı ve konumu ne olursa olsun bir şekilde bu tür olumsuzluklarla karşı karşıya gelebilmektedir. Doğal afetler, hastalıklar, ölümler, kayıplar, üzüntüler vs. insanın dünyada tercih etmediği fakat yaşamak zorunda kaldığı doğal ve beşerî acılardır. Mu’tezilî düşüncede insanın başına gelen elemlerin fâili Allah ise bunun bedelini ödemeyi vâcip konumunda üzerine almıştır. Fakat diğerine etki eden zarar ve zulümlerin neden olduğu acıların bedelini ödetecek olan da O’dur. Buna göre insanlara birçok acı yaşatan, öldüren, dokunulmazlarına saldıran bir insanın ahirette hak ettiği cezaya nispetle ödemesi gereken bedel, Mu’tezile'de ivaz olarak ifade edilmiştir.

Üstelik insan ihtiyar ve irade sahibi bir varlık olarak iyi ve kötüyü kasıtlı olarak planlayabilen ve yapabilen bir varlıktır. Onun bu özelliği değerlerin aynı zamanda iradî fiillerin ahlakî ve hukukî sonuçlarını kendisi

143 Kâdî Abdulcabbar, Serbu'l-usûli'l-hamse, 496.

144 Koloğlu, Cübbâileri’in Kelam Sistemi, 449-450. 
adına zorunlu kılmaktadır. Bu sebeple diğerine etki edebilen her fiil aynı zamanda bir hukukî süreci de var edebilmektedir. Ötekinin faydasina olan iyi, övgü ve mükâfatın hak edilmesini sağlarken; bireyin kendisi dışında özellikle diğerine yaptı̆̆1 kötülük, yergi ve cezanın hak edilme nedenini oluşturmaktadır. Bireylerin birbiriyle olan ilişkilerini en âdil şekilde tedbir üzere düzenleyecek olan da kuşkusuz Allah'tır.

Bunun için Mu'tezile'de geçişli (müteaddì) hakların sahiplerine teslimi için âdil ölçüt 'intisaf' kavramıla ifade edilmiştir. İntisaf, her hak sahibinin ahirette hukukî eşitliğini vurgulayan odak kavramlardan biridir. Intisafin pratik ve fayda değeri ise ivazdır. İvaz, Allah'ın ve insanın sebep olduğu acılara karşılık gelen hak edilmiş faydadır. İnsanın kendi tercihi veya iradesi dışında yaşatılan acının bedeli olarak aynı zamanda vacip bir değerdir. Bu sebeple mükâfat, ceza ve tefaddulden farklı bir anlam ve mahiyete sahiptir. Çünkü ivaz, bireyin günah gibi kendi emeği olmadan yaşadığ1 acının bedeli olarak gelecekte hak ettiği faydadır. Bu yönüyle ivaz, bütün insanlık için ortak bir değerdir. Herhangi bir varlığın istisna edilmesi bu noktada mümkün değildir. Şu durumda ivaz, inanan ve inanmayan, canlı ve cansız her bir varlığı içine alabilen tümel bir faydadır. İvazın bu özelliği aynı zamanda Allah'ın faydalandırma kastına, abes ve garaz dışı bir eylemde bulunmayacağına, varlık adına hikmetin temel bir ilke olduğuna, aslî/ontolojik olarak kötünün temellendirilemeyeceğine bir delil niteliği taşımaktadır. 


\section{KAYNAKÇA}

Arslan, Hulusi. Mu'tęile'ye Göre İyilik ve Kötülül-Husün ve Kubub Problemi. Doktora Tezi, Erciyes Üniversitesi, 2000.

Askerî, Ebu Hilâl el-Hasen b. Abdillah b. Sehl. el-Furuku'l-Luğaviyye. thk. Muhammed İbrahim Selim, Kahire: Dâru'l-İlm ve's-Sekafe, 1997.

Avn, Faysal Bedir. El-Usûlu'l-Hamseti'l-Mensûbî̀Ila'l-Kâdî̀-Abdilcabbar $b$. Ahmed el-Esedî el-Ebâdî. Kuveyt: 1998.

Aytepe, Mahsum. Kâdî Abdulcebbar'da Lütuf Teorisi. Doktora Tezi, Ankara Üniversitesi, 2014.

Bahrânî, Meysem b. Ali b. Meysem. Kavâidu'l-Merâm fî̀Ilmi'l-Kelâm. thk. Seyyid Ahmed el-Huseynî, Tahran: 1905.

Bedevî, Abdurrahman. Mezabibu'l-İslâmiyyîn. Beyrut: Dâru'l-İlm, 1998.

Câhız, Ebû Osman Amr b. Bahr b. Mahbûb. Kitabu'l-Hayevan. thk. Abdusselam Muhammed Harun, Kahire: 1965.

Carullah, Zühdî. el-Mu'tęile. Beyrut: 1974.

Cürcânî, Seyyid Şerif. “Zlm”. Mu'cemu'l-Ta'riffat. thk. Muhammed Siddık el-Minşavî, , Kahire: Dâru'l-Fazıle 2004.

Çelebi, İlyas. "İvaz". Türkiye Diyanet Vakfi Ansiklopedisi. 23: 488-490. İstanbul: TDV Yayınlar1, 2001.

Ebu'l Bekâ el-Kefevî, Eyyub b. Musa el-Huseynî. "Zlm”. el-Külliyyat. thk. Adnan Derviş-Muhammed el-Misrî, Beyrut: Müessesetü'r-Risâle, 1992.

Eş'arî, Ebu'l-Hasen Alî b. İsmâîl b. Ebî Bişr İshâk b. Sâlim. el-Kitabu'lLum'a fi'r-Red' ebli'r-Zeygri ve'l-Bid'. thk. Khamuda Gurabe, London: 1955.

Halil b. Ahmed el-Ferâhidî. "Avz". Kitâbu'l-Ayn. thk. Abdülhamid Hendâvî. 3: 255. Beyrut: Dâru'l-Kutubi'l-İlmiyye 2003.

Hanefî, Hasan. Mine'l-Akîde ila's-Sevra. Beyrut: 1988.

Hayyât, Ebu'l-Huseyn Abdurrahîm b. Muhammed b. Osman el-Mu'tezilî. Kitabu'l-Intisâr alâ-İbni'r-Ravendìl-Mulbid. thk. H. S. Nyberg, Beyrut: 1993. 
İbn Manzûr, Ebu'l-Fadl Muhammed b. Mükerrem b. Ali el-Ensarî. “Avz”. Lisânu'l-Arab. 9: 332. Beyrut: Dâru's-Sadr, 2010.

İbn Metteveyh, Muhammed b. Hasan b. Ahmed. Kitabu'l-Mecmû-fi'lMubit-bi't-Teklif. thk. Jan Peters, Kahire: 1986.

İbnü'l-Melâhimî Rüknüddîn el-Havârizmî, Mahmud b. Muhammed. Kitabu'l-Fâik fi-Usûli'd-Din. thk. Faysal Bedir Avn, Kahire: 2010.

İbn Murtaza, Ahmed b. Yahya, el-Munye ve'l-Emel, thk. Isâmuddîn Muhammed Ali, (ys:, 1985).

Kâdî Abdulcabbar, Ahmed el- Hamedânî el-Esedabâdî. Serbu'l-Usûli'lHamse. thk. Abdulkerim Osman, Kahire: Mektebetü-Vehbe, 1996.

Kâdî Abdulcabbar. Fazlu'l-Itizal ve Tabakâtü'l-Mu'tezile. thk. Fuad Seyyid, Kahire: Dâru'l-Kutubi'l-Misriyye, 1967

Kâdî Abdulcabbar. el-Muğnî fî-Ebvâbi't-Tevbid ve'l-Adl. thk. Muhammed Khodor Nabha, Beyrut: Dâru'l-Kutubi'l-İlmiyye, 2012.

Koloğlu, Orhan Şener. Cübbâileri’in Kelam Sistemi. İstanbul: İsam Yayınları, 2011.

Nisâburî, Ebu Reşîd Said b. Muhammed b. Said. Mesâilu'l-Hilaf-beyne'lBasriyyin ve'l-Bağdadiyyîn. thk. Maan Ziyade-Rıdvan es-Seyyid, Beyrut: 1979.

Ormsby, Eric Lee. İslam Düşüncesinde İlahî Adalet Sorunu. çev. Metin Özdemir, Ankara: Kitâbiyat Yayınları, 2001.

Osman, Abdülkerim. Nazariyyetü't-Teklif-Ârâu'l-Kâdî-Abdilcabbari'lKelâmiyye. Beyrut: 1971.

Seyyid, Muhammed Salih Muhammed. el-Hayr ve'ș-Şer inde'l-Kâdî Abdi'lCebbar. Kahire: 1998.

Subhî, Ahmed Mahmud. fî̀lmi'l-Kelam (Mu'tezile). Beyrut: Dâru'nNahzati'l-Arabiyye, 1985.

Şerif Murtazâ, Ali b. Huseyn el-Musevî el-Bağdâdî. el-Hudûd ve'l-Hakâike (Resâil'us-Şerif Murtazâa içerisinde). thk. Seyyid Ahmed el-Huseynî, Kum: 1405/1984. 
Şerif Murtazâ. ez-Zehîra fî̀Ilmi'l-Kelâm. thk. es-Seyyid Ahmed el-Huseynî, Kum: Müessesetü'n-Neşri'l-İslamî 1411/1990.

Tûsî, Ebu Cafer Muhammed b. el-Hasen. Keșfu'l-Murâd fì-Serbi'l-Tecrîdi'lİtikâd. şrh. Allâme Hillî, Beyrut: Müessesetü'l-Âlemî, 1988.

Tûsî, Ebu Cafer Muhammed b. El-Hasen. Tembîdu'l-Usûul (fî̀̇lmi'l-Kelâm), (Şerif Murtazâ'nın Cümelü'l-İlmi ve'l-Amel adlı eserinin ilk bölümüne yazılan şerh). thk. Merkezü't-Tehassusi li-İlmi'lKelami'l-İslamî, Kum: 1396/1976.

Zebîdî, Muhammed Murtazâ el-Huseynî. "Avz". Tâcu'l-Arûs, thk. Abdulkerim el-İzbâvî. 18: 449. Kuveyt: 1979. 